\title{
Mammalian Target of Rapamycin Inhibitors and Wound Healing Complications in Kidney Transplantation: Old Myths and New Realities
}

\author{
Muhammad Abdul Mabood Khalil ${ }^{D},{ }^{1}$ Saeed M. G Al-Ghamdi ${ }^{(D)}{ }^{2}$ \\ Ubaidullah Shaik Dawood $\mathbb{D}^{1},{ }^{1}$ Said Sayed Ahmed Khamis $\mathbb{D}^{3},{ }^{3}$ Hideki Ishida $\mathbb{D}^{4}$, \\ Vui Heng Chong $\mathbb{D}^{5}{ }^{5}$ and Jackson Tan $\mathbb{D}^{1}$ \\ ${ }^{1}$ Department of Nephrology, RIPAS Hospital, Bandar Seri Begawan BA1710, Brunei Darussalam \\ ${ }^{2}$ Department of Medicine Faculty of Medicine, King Abdul Aziz University, Jeddah 21589, Saudi Arabia \\ ${ }^{3}$ Department of Medicine Nephrology, Division Faculty of Medicine, Menoufia University Hospital, Shibin Al Kawm, Egypt \\ ${ }^{4}$ Department of Urology \&Transplant Services, Tokyo Women, s Medical University Hospital, 8-1 Kawada-cho, Shinjuku-ku, \\ Tokyo, Japan \\ ${ }^{5}$ Department of Medicine, RIPAS Hospital, Bandar Seri Begawan BA1710, Brunei Darussalam
}

Correspondence should be addressed to Muhammad Abdul Mabood Khalil; doctorkhalil1975@hotmail.com

Received 31 August 2021; Revised 12 December 2021; Accepted 8 January 2022; Published 28 February 2022

Academic Editor: Amar Singh

Copyright ( $\odot 2022$ Muhammad Abdul Mabood Khalil et al. This is an open access article distributed under the Creative Commons Attribution License, which permits unrestricted use, distribution, and reproduction in any medium, provided the original work is properly cited.

\begin{abstract}
Mammalian target of rapamycin inhibitors (mTOR-I) lacks nephrotoxicity, has antineoplastic effects, and reduces viral infections in kidney transplant recipients. Earlier studies reported a significant incidence of wound healing complications and lymphocele. This resulted in the uncomfortable willingness of transplant clinicians to use these agents in the immediate posttransplant period. As evidence and experience evolved over time, much useful information became available about the optimal use of these agents. Understandably, mTOR-I effects wound healing through their antiproliferative properties. However, there are a lot of other immunological and nonimmunological factors which can also contribute to wound healing complications. These risk factors include obesity, uremia, increasing age, diabetes, smoking, alcoholism, and protein-energy malnutrition. Except for age, the rest of all these risk factors are modifiable. At the same time, mycophenolic acid derivatives, steroids, and antithymocyte globulin (ATG) have also been implicated in wound healing complications. A lot has been learnt about the optimal dose of mTOR-I and their trough levels, its combinations with other immunosuppressive medications, and patients' profile, enabling clinicians to use these agents appropriately for maximum benefits. Recent randomized control trials have further increased the confidence of clinicians to use these agents in immediate posttransplant periods.
\end{abstract}

\section{Introduction}

The combination of calcineurin inhibitor (CNI), mycophenolic acid derivatives, and steroids has reduced acute rejection by $12 \%$ in 1 year [1]. However, it has not been translated into long-term survival. Functional graft loss due to cardiovascular diseases, malignancies, and infections is still the main reason for graft loss [2-6]. Another potential reason for failure to achieve long-term survival benefits is the nephrotoxicity of the calcineurin inhibitors. mTOR-I has also been successfully used to minimize $\mathrm{CNI}$ in various randomized control trials. Lack of nephrotoxicity, antineoplastic, and antiviral effects make mTOR-I a good choice for transplant nephrologists to combine them with low-dose CNI $[4,6]$. This maintains efficacy and reduces nephrotoxicity and viral infections in kidney transplant recipients. Unfortunately, mTOR-I's earlier use resulted in more wound healing complications and lymphocele. Wound healing complications occurred in $5-47 \%$ of the patient on sirolimus (SRL) $[7,8]$ and $6-40 \%$ inpatients on everolimus 
(EVL) $[9,10]$. Incidence of lymphocele is around $4-24 \%$ in SRL $[11,12]$ and $7-21 \%$ in EVL $[13,14]$. Wound healing complications and lymphocele formation can cause significant morbidity, longer hospital stays, more radiological investigations, and resurgical exploration or radiological intervention. This leads to an increased overall cost of transplantation. Recent randomized control trials on SRL and EVL have increased our insight into using these agents to gain maximum benefits and minimize its adverse events, including wound healing complications. Accumulating evidence has shown that other immunosuppressive medications, when used concurrently with mTOR-I, have a synergistic effect on wound healing complications. Medications implicated in wound healing complications other than mTOR-I include mycophenolic acid derivatives [15, 16], steroids [17], and ATG [18]. Similarly, various nonimmunological risk factors can also lead to wound healing complications. Nonimmunological factors include obesity, uremia, increasing age, diabetes, smoking, and protein-energy malnutrition. NEVERWOUND study is a randomized control trial that describes wound healing complications as fluid collection, including hematoma and lymphocele, prolonged lymphatic drainage (lymphorrhea), wound dehiscence, wound infection, urine leak, and incisional hernia [18]. Randomized studies which looked at these wound healing complications were thoroughly reviewed. This review focuses on the mechanism of these wound healing complications, how mTOR-I affects wound healing, risk factors for wound healing, and the way forward for optimal use of mTOR-I in light of the evidence available from randomized control trials.

\section{Mechanism of Action of mTOR-I}

The primary mechanism of action of mTOR-I is the inhibition of the mammalian target of rapamycin. It is a regulatory protein kinase involved in lymphocyte proliferation. When mTOR-I enters the cell, it binds a cytoplasmic receptor called FKBP-12. This receptor blocks serine-threonine kinase known as mTOR. This kinase (mTOR) is a downstream regulator of phosphatidyl inositol 3-kinase (PI13K) and protein kinase B (Akt). Both PI13K and AKT are activated by interleukin (IL-12, I-L15), oncogenes, vascular endothelial growth factor (VEGF), and cytomegalovirus, which activates mTOR leading to the proliferation of lymphocytes, tumor cells, cytomegalovirus, and endothelial cells. mTOR-I blocks mTOR and leads to reduced lymphocytes, endothelial cells, tumor cells, and cytomegalovirus $[19,20]$. These agents cause interaction inhibition among mTOR Complex 1 (mTORC1), mTOR Complex 2 (mTORC2), and PI3K. Currently, there are two mTOR-I available. Sirolimus (SRL) is a macrolide lactone produced by Streptomyces hygroscopicus and has a long half-life of 62 hours. EVL is one of the derivatives of SRL and has a similar structure but has a covalently attached 2hydroxyethyl group at position 40, leading to improved bioavailability and reducing the half-life of 26 hours $[21,22]$.

\section{3. mTOR-I and Mechanism of Impaired Wound Healing and Lymphocele Formation}

The wound healing process consists of four phases: hemostasis, inflammation, proliferation, and tissue remodeling or resolution [23]. Hemostasis consists of vascular constriction, platelet aggregation, degranulation, and fibrin formation (thrombus). The phase of inflammation includes infiltration of neutrophils, lymphocytes, and monocyte and its differentiation to macrophages. The proliferation phase includes reepithelialization, angiogenesis, collagen synthesis, and extracellular matrix formation. The final remodeling phase includes collagen remodeling, vascular maturation, and regression [24].

Tcells and various cytokines play an essential role in wound healing. Various studies showed that late infiltration and reduced T cells at wound sites are associated with wound healing problems [24]. Similarly, impaired angiogenesis and reduced fibroblast activity have been implicated in wound healing $[25,26]$. Vascular endothelial growth factor (VEGF) and nitrous oxide are essential mediators for angiogenesis and collagen synthesis and play a critical role in wound healing [27, 28]. mTOR-I binds FK binding protein (FKBP) and acts on the mTOR. mTOR regulates the phosphoinositide 3-kinase/Akt pathway, which is stimulated by interleukin-2 and other cytokines [29]. It also affects cell cycle progression and angiogenesis. As a result, mTOR inhibition will cause inhibition of lymphocyte, endothelial, and fibroblast proliferation. mTORI also causes a reduction of VEGF and NO [30]. Inhibition of endothelial and fibroblast cells by mTOR-I leads to impaired angiogenesis and fibroblastic activity [25, 31].

There are various animal studies on the pathophysiology of wound healing. It has been shown that hypoxia increases DNA synthesis and proliferative effects of platelet-derived growth factor (PDGF) and fibroblast growth factor (FGF) in rat and human smooth muscle and endothelial cells. This effect is dependent on mTOR activation downstream enzyme, phosphatidyl inositol 3-kinase. Rapamycin has been shown in rats to impair wound healing by blocking this enzyme [31]. Intraepithelial lymphocytes, $\gamma \delta \mathrm{T}$ cells in the skin, help in wound healing, and depletion of these cells with rapamycin results in delayed wound healing in rats [32]. EVL has been shown to cause a reduction in hydroxyproline and collagen deposition in wounds resulting in reduced breaking strength and bursting pressure of ileal and colonic anastomosis in the rat model [33]. Similar effects were seen in the abdominal wound in rats in another study [34]. Bladder healing was assessed in rats in another study. It showed that eosinophil and neutrophil infiltration and myofibroblast proliferation were significantly lower in the bladder, fascia, and dermis of the rats who received rapamycin compared to the control group. Mean microvessel density and the percentage of cells expressing vascular endothelial growth factors in the bladder, fascia, and dermis were also significantly lower among rapamycin [35]. In a study done in pigs to assess ureteric anastomosis, the tensile strength and the hydroxyproline levels in the ureter and fascia were lower in the rapamycin-treated group [36]. Yet, 
TABLE 1: Animal studies on mTOR-I to study its impact on wound healing.

\begin{tabular}{|c|c|c|c|c|}
\hline Reference & Journal/year & Objective & Intervention & Finding \\
\hline $\begin{array}{l}\text { Dantal et al. } \\
{[10]}\end{array}$ & Faseb Journal/2002 & $\begin{array}{l}\text { Hypoxia increases DNA } \\
\text { synthesis and proliferative } \\
\text { response to platelet-derived } \\
\text { growth factor (PDGF) and } \\
\text { fibroblast growth factor (FGF) } \\
\text { in rat and human smooth } \\
\text { muscle and endothelial cells. It } \\
\text { is dependent on mTOR } \\
\text { activation downstream enzyme } \\
\text { phosphatidyl inositol 3-kinase. } \\
\text { Rapamycin blocks these effects } \\
\text { and inhibits fibrogenesis and }\end{array}$ & $\begin{array}{l}\text { Primary cultures of rat aortic } \\
\text { smooth muscle cells were } \\
\text { isolated from fresh rat aortas. } \\
\text { Aortas were denuded from } \\
\text { endothelium and adventitia and } \\
\text { the aortic media was fragmented } \\
\text { mechanically and subcultured. } \\
\text { Effect of hypoxia and activity of } \\
\text { PI3K were analyzed. Effect of } \\
\text { rapamycin on hypoxia induced } \\
\text { proliferation was also analyzed. }\end{array}$ & $\begin{array}{l}\text { Hypoxia increases PDGF- and } \\
\text { FGF-induced proliferation of } \\
\text { vascular wall cells. PI3K activity } \\
\text { is required for the proliferative } \\
\text { response of vascular cells and } \\
\text { angiogenesis in vitro under } \\
\text { normoxia and hypoxia. } \\
\text { Rapamycin specifically inhibits } \\
\text { the hypoxia-mediated increase } \\
\text { in growth factor-mediated } \\
\text { vascular cell proliferation. }\end{array}$ \\
\hline
\end{tabular}

Intraepithelial lymphocytes, $\gamma \delta \mathrm{T}$ cells in the skin helps in tissue repair via cytokine and growth factor. The function of this $\mathrm{T}$ cell was analyzed as rapamycin treatment in a mouse model of wound repair.

Vitko et al. Journal of [11] Immunology/2008

Durrbach Transplantation/ et al. [12] 2006

Vitko et al. Wound repair and [13] regeneration/2009
To study the effect of EVL in both intestine and abdominal wall in rats over a period of 4 weeks.
Wildtype C57BL/6J mice were given daily rapamycin or vehicle control for three days before wounding. This treatment was continued after wound for total of 14 days.

4 groups of male Wistar rats were given $0 \mathrm{mg}$ (group 1, control), $0.5 \mathrm{mg}$ (group 2), $1 \mathrm{mg}$ (group 3), and $3 \mathrm{mg}$ (group 4) starting 4 hours before colonic and iliac anastomosis until killing on day 3 or day 7 of operation.
Fewer wounds were closed on day 10 in rapamycin-treated mice as compared to vehicle control treated animals. Delay on day 3 wound closure was found which was similar mice lacking $\gamma \delta \mathrm{T}$ cells (TCR $\delta-/-$ mice).

There was no difference on day 3 . Breaking strength and bursting pressure were reduced on day 7 in EVL group. There was reduction in hydroxyproline content and there was less collagen deposition in the wound. The effects were more pronounced in higher EVL group of $3 \mathrm{mg}$.

Wistar rats received a daily dose of 1 or $2 \mathrm{mg} / \mathrm{kg}$ EVL orally, from the operation day onwards.

Controls received saline. In each rat, a resection of ileum and colon was performed, and endto-end anastomoses were constructed. On day 7,14 , and

Wistar rats received a daily dose 28 , the animals were killed and of 1 or $2 \mathrm{mg} / \mathrm{kg}$ EVL orally, from anastomoses and abdominal wall the operation day and control was given saline onwards.

Controls received saline. All rats have resection of ileum and colon with end-to-end anastomosis, and on day 7,14 , and 28 , animals were killed.

Their abdominal and anastomotic wounds were assessed for wound strength. wounds were analyzed, wound strength being the primary

parameter. Breaking strength of ileum, colon, and fascia was consistently and significantly reduced in the experimental groups. Anastomotic bursting pressures followed the same pattern. Loss of strength was accompanied by a decrease in hydroxyproline content after 7 days. Thus, the negative effect of EVL on wound repair persists for at least 4 weeks after operation in this rodent model. This protracted effect may have clinical consequences and cause surgical morbidity. 
TABle 1: Continued.

\begin{tabular}{|c|c|c|c|c|}
\hline Reference & Journal/year & Objective & Intervention & Finding \\
\hline $\begin{array}{l}\text { Salvadori } \\
\text { et al. [14] }\end{array}$ & $\begin{array}{l}\text { Transplantation } \\
\text { Proceeding/2007 }\end{array}$ & $\begin{array}{l}\text { To see the effects of rapamycin } \\
\text { on the healing of bladder and } \\
\text { abdominal wound closures. }\end{array}$ & $\begin{array}{l}\text { Study was done in } 14 \text { male rats. } \\
\text { Rapamycin }(3 \mathrm{mg} / \mathrm{d}) \text { or placebo } \\
\text { was given to them. Midline } \\
\text { abdominal incision was given } \\
\text { and bladder was cut and closed } \\
\text { with } 4-0 \text { vicryl. }\end{array}$ & $\begin{array}{l}\text { Eosinophil and neutrophil } \\
\text { infiltration and myofibroblast } \\
\text { proliferation were significantly } \\
\text { higher in bladder, fascia, and } \\
\text { dermis of the control group. } \\
\text { Lymphocyte's infiltration was } \\
\text { the same in both groups. Mean } \\
\text { microvessel density as well as the } \\
\text { percentage of cells expressing } \\
\text { vascular endothelial growth } \\
\text { factor in the bladder, fascia, and } \\
\text { dermis were significantly lower } \\
\text { among rapamycin. }\end{array}$ \\
\hline $\begin{array}{l}\text { Büchler } \\
\text { et al. [15] }\end{array}$ & $\begin{array}{l}\text { Transplantation } \\
\text { Proceeding/2005 }\end{array}$ & $\begin{array}{l}\text { To see the effect of rapamycin } \\
\text { on wound healing and the } \\
\text { healing of the ureteric } \\
\text { anastomosis. }\end{array}$ & $\begin{array}{l}\text { Pigs underwent laparotomy and } \\
\text { excision of the ureter followed by } \\
\text { anastomosis of the ureter. The } \\
\text { animals were randomly allocated } \\
\text { to receive either rapamycin or } \\
\text { placebo. The animals were } \\
\text { sacrificed on postoperative day } 5 . \\
\text { Skin, fascia, and ureteric tissues } \\
\text { were assessed for the tensile } \\
\text { strength, hydroxyproline levels, } \\
\text { and histological changes. }\end{array}$ & $\begin{array}{l}\text { The tensile strength and the } \\
\text { hydroxyproline levels in the } \\
\text { ureter and fascia were lower in } \\
\text { the rapamycin-treated group. } \\
\text { However, there was no } \\
\text { difference in the tensile strength } \\
\text { in the skin, although the } \\
\text { hydroxyproline levels were } \\
\text { lower. }\end{array}$ \\
\hline $\begin{array}{l}\text { Flechner } \\
\text { et al. [16] }\end{array}$ & $\begin{array}{l}\text { European Journal of } \\
\text { Cardiothoracic } \\
\text { Surgery/2003 }\end{array}$ & $\begin{array}{l}\text { SDZ RAD (40-0 (2- } \\
\text { hydroxyethyl)-rapamycin), a } \\
\text { rapamycin derivative, inhibits } \\
\text { fibroblast proliferation and may } \\
\text { limit development of } \\
\text { bronchiolitis obliterans. But, it } \\
\text { may impair the healing of the } \\
\text { bronchial anastomoses. }\end{array}$ & $\begin{array}{l}\text { The cervical trachea in pigs was } \\
\text { divided and reanastomosis was } \\
\text { done. One group was given SDZ } \\
\text { RAD for } 14 \text { days and control } \\
\text { group was given none. }\end{array}$ & $\begin{array}{l}\text { SDZ RAD significantly reduced } \\
\text { the breaking strength of the } \\
\text { tracheal anastomosis. However, } \\
\text { no differences in histological } \\
\text { samples were found between two } \\
\text { groups. }\end{array}$ \\
\hline
\end{tabular}

in another study in pigs, although rapamycin derivatives prevented the development of bronchiolitis obliterans, it impaired the healing of bronchial anastomosis [37]. These animal studies suggest that mTOR-I impairs the ability of wound healing. Summaries of all these studies are included in Table 1.

Lymphocele $l$ is a pseudocyst with lymph inside with an outside hard, fibrous capsule. It is usually adjacent to the graft $[38,39]$. mTOR-I has been shown to have antilymphoangiogenic effects during surgical wound healing both in vitro and in vivo. It was demonstrated that VEGF-C plays an essential role in lymphangiogenesis. EVL and SRL inhibit this intracellular mediator of lymphangiogenesis [40].

\section{Is It mTOR-I Only?}

Besides mTOR-I, various studies conducted in animal and clinical settings have implicated other immunological medications and nonimmunological factors in wound healing complications. Therefore, it is important to investigate these factors and do a fair analysis of all these factors to reach the root cause analysis of wound healing events. Figure 1 shows all the risk factors of wound healing complications.

These immunological and nonimmunological factors which result in impaired wound healing are as follows.
4.1. Mycophenolic Acid Derivatives. Mycophenolic acid derivatives include mycophenolate mofetil (MMF) and its metabolites, mycophenolic acid (MPA). It is a highly selective, noncompetitive, and reversible inhibitor of the inosine monophosphate dehydrogenase. It is the ratelimiting enzyme for de novo biosynthesis of guanosine nucleotides [41]. Guanosine nucleotides are important for DNA replication and RNA and protein synthesis. Various experimental studies have shown that MMF/MPA affects various body cells and collagen synthesis. These agents inhibit the proliferation of both $T$ and $B$ lymphocytes. MMF has been shown to cause downregulation of cytoskeleton proteins vinculin, actin, and tubulin in fibroblasts exposed to pharmacological doses of MPA. Skin biopsies of patients treated with MPA expressed less vinculin, actin, and tubulin than control biopsies, which could be a potential explanation for impaired wound healing [42]. Willem et al. showed in the rodent model that MMF may negatively affect the abdominal wall wound healing but had no effect on colonic anastomosis [43]. The bladder wound of rats treated with tacrolimus (TAC) and MMF has more immature collagen (type III) as compared to the control group, which has mature collagen (type I) [44]. MMF may cause inhibition of fibroblast by depletion of guanosine. Human tenon fibroblasts were cultured with various concentrations of MMF with and without guanosine, and it 


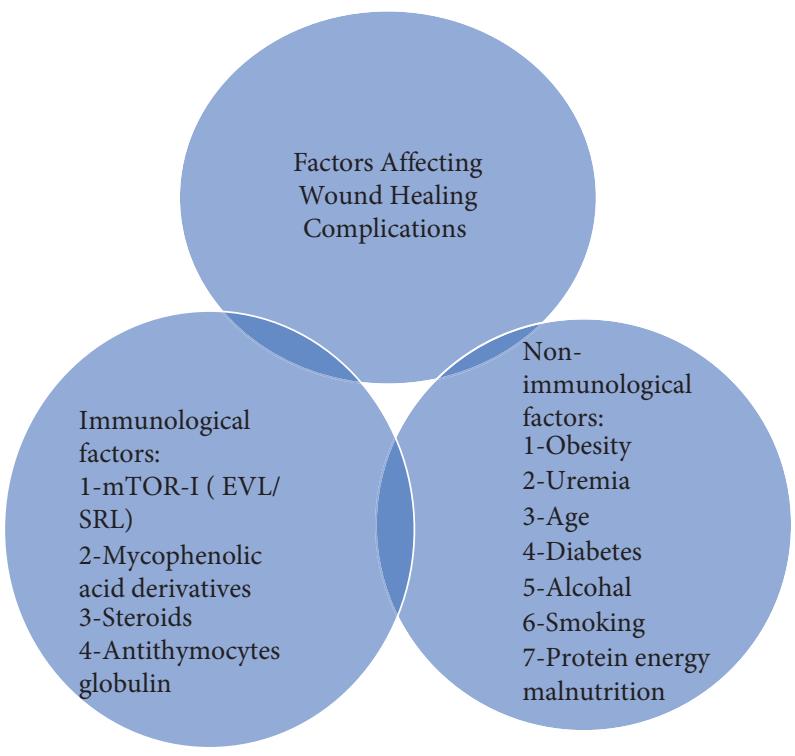

Figure 1: Factors associated with wound healing complications.

was shown that growth of tenon fibroblast was inhibited in a concentration-dependent way. These effects were reversed with guanosine [45]. MMF has been shown to inhibit the growth of nonimmune cells, including tubular cells [46], mesangial cells [47, 48], and myointerestitial fibroblasts [49] in the kidneys and has a potential role in proliferative glomerulonephritides and slowing down interstitial fibrosis and tubular atrophy in kidney transplant patients. In clinical studies, MMF has been implicated in causing wound healing complications in $16.6 \%$ of kidney transplant recipients [50]. In a retrospective analysis, more lymphoceles $(\mathrm{OR}=2.6 ; p=0.03)$, fluid drainage ( 17 vs. 5 interventions), and sclerotherapies (8 vs. 0 ) were observed in MMF group as compared to azathioprine (AZA) [51]. MMF has been implicated along with SRL in wound healing complications in several randomized control trials. However, it is difficult to assess the individual agent's impact on wound healing because of its use in combination with mTOR-I. In a prospective randomized control trial, hernial eventration/wound evisceration was 7/71 in the SRL-MMF group compared to $0 / 71$ in the ciclosporin (CsA)-MMF group [52]. In the ORION study, SRL-MMF had significantly higher wound healing complications than the SRLTAC elimination group ( $23 \%$ vs. $16.4 \%, p<0.05)$. Similarly, the incidence of lymphocele was also significantly higher in the SRL-MMF group [16]. In the SYMPHONY trial, $17 \%$ of patients had delayed wound healing in low-dose SRL and MMF groups, significantly higher than other groups ( $p$ value $=0.006$ ). The incidence of lymphocele was $15.8 \%$ which was also significantly higher in the SRL-MMF group when compared to other groups ( $p$ value $<0.001$ ) [1]. In the TRANSFORM trial, wound healing complications were $19.8 \%$ in EVL compared to $16.2 \%$ in the MPA group, with relative risk between the two groups being 1.22 (1.01 to 1.47) [53]. In a meta-analysis of randomized control trials, the incidence of wound healing complications (OR 3.00, CI 1.61-5.59) and lymphocele (OR 2.13, CI 1.57-2.90) were significantly higher in mTOR-I and MMF as compared to mTOR-I and calcineurin inhibitor [54]. Table 2 shows the summary of experimental studies and studies conducted in a clinical setting on mycophenolic derivatives on wound healing complications.

4.2. Steroids. Corticosteroids cause wound healing complications by a variety of mechanisms. Corticosteroids reduce inflammation, fibroblast proliferation, collagen synthesis, angiogenesis, and reepithelialization [55]. In vitro studies conducted in an animal model have shown that steroids cause impaired wound healing through various mechanisms. Methyl prednisolone treatment has been shown to decrease transforming growth factor beta (TGFbeta) and insulin-like growth factor I (IGF-I) in the wound fluid and hydroxyproline content in the tissue $(p<0.05)$ in rats' model [56]. In another study, administration of hydrocortisone in mice reduced the skin wound healing resistance during the first postoperative week [57]. Steroids have also been implicated as risk factors in a retrospective analysis of abdominal wounds complicated by dehiscence in the general population [58].

In several randomized control trials, steroids avoidance led to fewer wound complications. Sandrini et al. showed that overall wound complications were significantly lower in the off-steroids group than those on steroids $(18.8 \%$ vs. $45.6 \%$, respectively, $p<0.0004)$. Similarly, incidence of lymphocele $(5.0 \%$ vs. $32.3 \%, p<0.0001)$ and dehiscence ( $0 \%$ vs. $10.3 \%$, $p<0.009)$ were significantly lower in steroids avoidance group [17]. The addition of steroids to SRL increases 4.2-fold the risk for wound complications [17]. In another to randomized control trial, the incidence of lymphocele was higher in steroid-free regimens than low-dose steroids $(1.5 \%$ vs. $5.9 \%)$, but it was not statistically significant [59]. Roger et al. compared 109 patients treated with a corticosteroid avoidance regimen with a historical control group $(n=72)$ that received 
TABLE 2: Experimental and clinical studies performed on mycophenolic acid derivatives and their effects on wound healings.

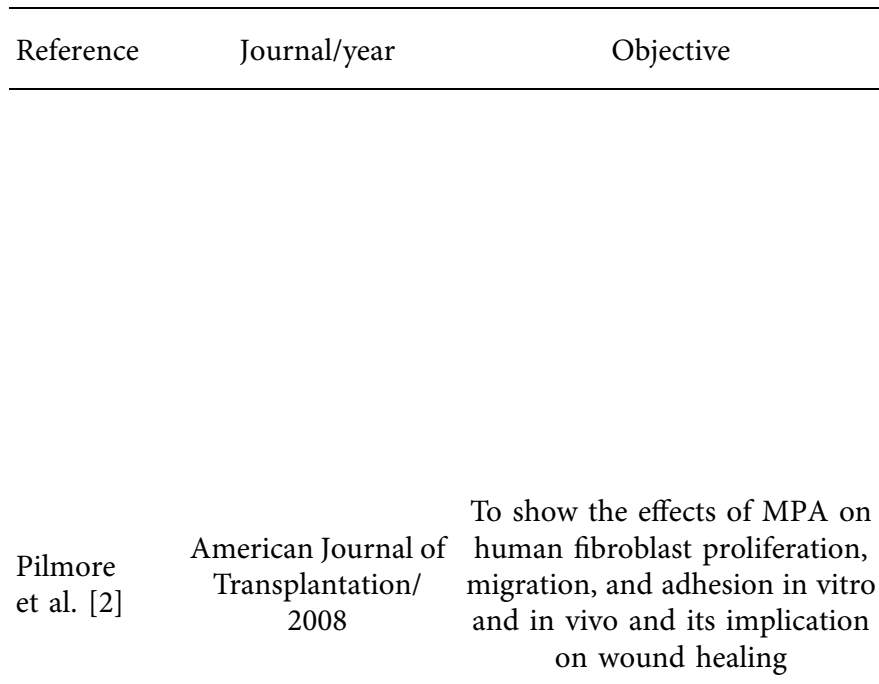
Engels et al. Transplant Direct/ [3] 2016

To study the effect of MMF on wound healing in rodent model after 3 days and half after 7 days.

To study the synthesis of type I (received $0.1 \mathrm{mg} / \mathrm{kg} / \mathrm{day}$ of TAC (mature) and type III

Yanik et al. [4]

Int Braz J Urol/2014 (immature) collagen in bladder suture of rats treated with a combination of TAC and MMF for 15 days.
Human fibroblast was cultured. Expression of cytoskeletal proteins vinculin, actin, and tubulin in fibroblasts was assessed by polymerase chain reaction (PCR) and western blot. RNA and protein content and its effect on rearrangement on cytoskeleton was assessed by

immunofluorescence. Scratch test was done to assess reduced migration activity. The results of the cultured human fibroblasts were applied to skin biopsies of renal transplant recipients. Skin biopsies of patients treated with MPA were assessed with control.

4 groups were made from ninetysix male Wistar rats. All the groups underwent anastomotic construction in ileum and colon at day 0 . Three groups received daily oral doses of 20 or $40 \mathrm{mg} / \mathrm{kg}$ MMF or saline (control group) from day 0 until the end of the experiment. Half of each group was analyzed 4th group started the medication 3 days after the laparotomy and was analyzed after 7 days. Half of the 4 th group received $20 \mathrm{mg} / \mathrm{kg}$ and half $40 \mathrm{mg} / \mathrm{kg}$ MMF. Wound strength in anastomoses and in the abdominal wall was measured by assessing bursting pressure, breaking strength, and histology. Thirty rats were grouped into 3 groups: the sham (did not receive any treatment), control (saline solution), and experimental groups

Finding relevant to fibroblast growth and wound healing

The authors showed a downregulation of the

cytoskeletal proteins vinculin, actin, and tubulin in fibroblasts exposed to pharmacological doses of

MPA. This reduction in RNA and protein content is accompanied by a substantial rearrangement of the

cytoskeleton in MPA-treated fibroblasts. The dysfunctional fibroblast growth was validated by scratch test documenting impaired migrational capacity. In contrast, cell adhesion was increased in MPA-treated fibroblasts. The results of the cultured human fibroblasts were applied to skin biopsies of renal transplant recipients. Skin biopsies of patients treated with MPA expressed less vinculin, actin, and tubulin as compared to control biopsies.

On day 3 , it was shown that there was stronger anastomosis in the experimental groups. Bursting pressure as well as breaking strength were higher in the low-dose and high-dose MMF group compared with the control group. However, wound strength in abdominal wound was less in the highest MMF group.

Type I collagen production and deposition in the sham with $20 \mathrm{mg} / \mathrm{kg} /$ day of MMF). All treatments were given for 15 days. All the animals underwent laparotomy, cystotomy, and bladder suture in two planes with surgical PDS 5-0 thread. The surgical specimens of the bladder suture area were assessed for the type of collagen deposition. and control groups were more as compared to the experimental group. TAC and MMF change qualitatively to collagen type III in wound 
TABle 2: Continued.

\begin{tabular}{|c|c|c|c|}
\hline Reference & Journal/year & Objective & Intervention \\
\hline $\begin{array}{l}\text { Eckl et al. } \\
{[5]}\end{array}$ & $\begin{array}{l}\text { Br J Ophthalmol/ } \\
2003\end{array}$ & $\begin{array}{l}\text { To study if growth inhibition of } \\
\text { MMF on human tenon } \\
\text { fibroblasts is mediated by } \\
\text { guanosine depletion. }\end{array}$ & $\begin{array}{l}\text { Human tenon fibroblasts were } \\
\text { cultured incubated in various } \\
\text { concentrations of MMF with and } \\
\text { without supplementation of } \\
\text { guanosine. }\end{array}$ \\
\hline $\begin{array}{l}\text { Tedesco- } \\
\text { Silva et al. } \\
{[6]}\end{array}$ & $\begin{array}{c}\text { Nephrol Dial } \\
\text { Transplant. } 2000 \\
\text { Feb; } 15 \text { (2):184-90. }\end{array}$ & $\begin{array}{l}\text { To study the effect of MMF on } \\
\text { proximal convoluted tubules } \\
\text { (PCT) and distal convoluted } \\
\text { tubules (DCT). }\end{array}$ & $\begin{array}{l}\text { Human PTC and DTC were } \\
\text { cultured in the presence of } \\
\text { different concentrations of MPA } \\
(0.25-50 \text { microM }) \text { or MPA plus } \\
\text { guanosine (100 microM). Cells } \\
\text { were stimulated by a combination } \\
\text { of cytokines. Secretion of RANTES } \\
\text { protein was evaluated. Cell surface } \\
\text { expression of HLA-DR and ICAM- } \\
1 . \\
\text { Primary cultures of HMC and of }\end{array}$ \\
\hline
\end{tabular}

$\begin{array}{lc}\text { Franz et al. } & \text { Kidney } \\ \text { [7] } & \text { International/2002 }\end{array}$

Dean et al. Nephrol Dial

[8] Transplant/1999

de Fijter

et al. [9]

Kidney Int/2000

To investigate the effect of MMF

on whether it reduces interstitial myofibroblast infiltration.
Forty-five rats underwent renal ablation. One group received daily dose of vehicle (N 5/20). The other group received MMF (N 5/25).

This was continued during the 60 days following surgery.
Dantal et al. Transplantation/ [10]
1998
The objective of the study was to avoid the nephrotoxic effects by
CsA avoidance using MMF during induction and maintenance.

Finding relevant to fibroblast growth and wound healing

Tenon fibroblast growth was inhibited in a concentrationdependent way. It was reversed by guanosine supplement.

MPA inhibited cell growth of PTC and DTC in a dosedependent manner. This effect was totally abolished by the addition of guanosine.

Treatment of cultured HMC with MPA inhibited mesangial cell proliferation and matrix production.

( 1 to $10 \mathrm{~mol} / \mathrm{L}$ ) for 24 hours.

The growth of fetal rat and human MCs were arrested by taking out fetal calf serum (FCS) and then stimulated by addition of FCS, platelet-derived growth factor (PDGF), or lysophosphatidic acid. Different concentrations of MMF (0.019-10 microM) were added concomitantly in the presence or absence of guanosine.

Cellular proliferation in renal tubules, interestitium, and glomeruli along with myofibroblast infiltration in interestitium and interstitial type III collagen deposition were significantly reduced by MMF treatment. MPA showed a dose-dependent inhibitory effect on in vitro proliferation of rat fibroblasts. MMF treatment improved renal function and resulted in reduced kidney hypertrophy and glomerular volume parameters and progressively decreased remnant kidney hypertrophy and glomerular volume increment.

In primary CsA, free induction methyl prednisolone and ATG were given during induction and oral MMF 1 gram twice a day was given within 24 hours after surgery. In late group, CsA was withdrawn after 4 weeks slowly (25 mg/day) and was kept on MMF.
Wound healing complications occurred in $16.6 \%$ of MMF treated patients. 
TABle 2: Continued.

\begin{tabular}{|c|c|c|c|c|}
\hline Reference & Journal/year & Objective & Intervention & $\begin{array}{l}\text { Finding relevant to fibroblast } \\
\text { growth and wound healing }\end{array}$ \\
\hline $\begin{array}{l}\text { Vitko et al. } \\
\text { [11] }\end{array}$ & $\begin{array}{c}\text { Kidney Blood Press } \\
\text { Res } / 2010\end{array}$ & $\begin{array}{l}\text { Retrospective study to assess } \\
\text { MMF on wound healing and } \\
\text { lymphocele formation. }\end{array}$ & $\begin{array}{l}\text { Retrospective single-center } \\
\text { analysis of } 144 \text { patients receiving a } \\
\text { CsA-based immunosuppression } \\
\text { with prednisolone (Pred) and } \\
\text { either MMF ( } n=77 \text { ) or AZA } \\
\text { (AZA, } n=77 \text { ) was done. The end } \\
\text { points were lymphocele and } \\
\text { nonprimary wound healing during } \\
6 \text { months follow-up. }\end{array}$ & $\begin{array}{l}\text { More lymphoceles were } \\
\text { observed in MMF group } \\
\text { (OR=2.6; } p=0.03) \text {. More } \\
\text { fluid drainage ( } 17 \text { vs. } 5 \\
\text { interventions) and } \\
\text { sclerotherapies ( } 8 \text { vs. } 0) \text { were } \\
\text { done in MMF group. }\end{array}$ \\
\hline $\begin{array}{l}\text { Durrbach } \\
\text { et al. [12] }\end{array}$ & $\begin{array}{l}\text { Am J Transplant/ } \\
2003\end{array}$ & $\begin{array}{l}\text { Retrospective analysis of effect of } \\
\text { SRL vs. MMF on surgical } \\
\text { complications and wound } \\
\text { healing in adult kidney } \\
\text { transplant recipients. }\end{array}$ & $\begin{array}{l}\text { Patients on MMF and SRL were } \\
\text { retrospectively analyzed for wound } \\
\text { healing complication via logistic } \\
\text { regression analysis. }\end{array}$ & $\begin{array}{l}\text { The incidence of wound } \\
\text { complications was statistically } \\
\text { different for patients receiving } \\
\text { MMF compared to SRL: } 2.4 \% \\
\text { for group 1 vs. } 43.2 \% \text { for } \\
\text { group } 2(p<0.0001) \text {. }\end{array}$ \\
\hline
\end{tabular}

study was done to compare the safety and efficacy of an SRL-

Vitko et al. Am J Transplant/ [13] 2007 MMF-based regimen with a CsA

-MMF-based regimen after induction therapy with polyclonal antilymphocyte antibodies, with withdrawal of steroids 6 months.

To assess safety and efficacy of Salvadori Am J Transplant/ two SRL, dosing regimens were et al. [14] $2011 \quad$ compared with TAC and MMF (ORION study)

To assess adverse events in

Büchler et al. [15] J Am Soc Nephrol/ 2018 kidney transplant recipient who received different immunosuppressive

To do metanalysis to assess if wound complications or

Pengel LH et al. [SRL $16]$

Transpl Int/2011

lymphoceles occur more often in solid-organ transplant recipients on mTOR inhibitors.
Primary end point was graft function at 12 months. Secondary outcome included acute rejection, delayed graft function, slow graft function, and CMV infection.

Patients were randomized to group 1 (SRL + TAC); week 13 TAC elimination, group 2

$(\mathrm{SRL}+\mathrm{MMF})$, or group 3 $(\mathrm{TAC}+\mathrm{MMF}))$.

Kidney transplant recipient undergoing kidney transplant received low-dose SRL or CsA (TAC or SRL) in addition to daclizumab induction or standarddose CsA without induction. All patients received MMF and corticosteroids.

Metanalysis of 17 randomized control trials was done.
Hernial eventration/wound evisceration was in 7/71 in SRL-MMF group as compared to $0 / 71$ in CsA-MMF group

Delayed wound healing was present in $16.4 \%$ (SRL-TAC elimination group) and $23 \%$ (SRL + MMF) with $p<0.05$ between the two groups. Lymphocele was present in $18.4 \%$ in SRL-MMF group. $17 \%$ patients have delayed wound healing in low-dose SRL and MMF and was significant as compared to another group with $p$ value $=0.006$. The incidence of lymphocele was $15.8 \%$ in lowdose SRL-MMF and was significant as compared to other groups with $p$ value $<0.001$.

Incidence of wound healing complications (OR 3.00, CI 1.61-5.59) and lymphocele (OR 2.13, CI 1.57-2.90) were significantly higher in mTORI and MMF as compared to mTOR-I and calcineurin inhibitor where incidence of wound healing complications was (OR 1.77, CI 1.31-2.37) and that of lymphoceles (OR 2.07, CI 1.62-2.65) [17].
CsA, MMF, and steroids. The corticosteroids avoidance group has lower incidence of wound healing complications $(13.7 \%$ vs. $28 \%, p=0.03$ ) and lymphoceles (5.5\% vs. $16 \%, p=0.02)$ than the control group [60].
Steroids use in humans has shown that high-dose corticosteroid administration for $<10$ days has no clinically significant effect on wound healing. In patients taking chronic corticosteroids for at least 30 days before surgery, 
their rates of wound complications may be increased 2 to 5 times compared with those not taking corticosteroids [61].

4.3. Antithymocyte Globulin (ATG). Various studies have also implicated ATG in wound healing problems. Benavides et al. [62] studied wound healing complications in patients receiving rabbit antithymocyte globulin (rATG) induction for a maximum of two weeks postoperatively. Patients receiving ATG: $39.1 \%$ patients have significant wound healing complications compared to $26.0 \%$ basiliximab induction $(p=0.025)$. Pourmand et al. found a significant relationship between ATG therapy and wound complications $(p=0.034)$ [63]. These findings were confirmed in the NEVERWOUND study, which reported an increased risk of wound healing $>60 \%$ while using ATG induction [18].

4.4. Obesity. Obesity is another important risk factor accounting for wound complications. Around $34.5 \%$ of kidney transplant recipients have a body mass index (BMI) greater than 30 [64]. Wound infection and dehiscence are more when BMI is $>30$ [65]. The risk of wound healing complications goes up with the severity of obesity. Andrade et al. assessed the effect of weight on wound complications in underweight $\left(\mathrm{BMI}<20 \mathrm{~kg} / \mathrm{m}^{2}\right)$, normal weight $(20 \leq \mathrm{BMI}<25)$, overweight $(25 \leq \mathrm{BMI}<30)$, class I obese $(30 \leq \mathrm{BMI}<35)$, class II obese $(35 \leq \mathrm{BMI}<40)$, and class III obese $(\mathrm{BMI} \geq 40)$. There was a significantly increased risk of wound complications by 1.9-fold for every 5 points increase in BMI $(p<0.001)$, and wound complications were observed $17.5,29.0,45.0$, and $60 \%$ with BMIs of $30,35,40$, and 45 , respectively, in each group [64]. In an analysis of data of 869 kidney transplant recipients, Lynch et al. [64] reported a graded increase in the frequency of wound infection from $8.5 \%$ among those with BMI 20-25 to $40 \%$ among those with $\mathrm{BMI}>40$ [66]. In another study conducted on SRL to assess risk factors for wound healing, obesity was an important contributor. The authors compared SRL-MMF patients with complications within three months of transplantation with SRL-MMF patients without complications and matched renal transplant recipients receiving TAC-MMF. Obesity $\left(B M I \geq 30 \mathrm{~kg} / \mathrm{m}^{2}\right)$ was significantly associated with wound problems. The mean BMI of SRL cases with complications was $29.9 \mathrm{~kg} / \mathrm{m}^{2}$ compared to $25.4 \mathrm{~kg} / \mathrm{m}^{2}$ for SRL patients without complications $(p=0.047)$. Seventy-one percent of obese SRL patients experienced complications compared with $24.3 \%(p=0.025)$ of nonobese SRL patients [67]. Another retrospective analysis assessed risk factors for wound healing complications in patients receiving de novo SRL, low-dose CsA, and corticosteroid. Multivariate analysis showed that body mass index $(\mathrm{BMI})>26$ (odds ratio 2.498, $p=0.027$ ) was a significant risk factor for wound healing complications in patients taking SRL. The risk was even higher with $\mathrm{BMI}>30$ (odds ratio 3.738, $p=0.007$ ) [68]. In a prospective randomized trial using high-dose SRL $(15-20 \mathrm{ng} / \mathrm{mL})$, wound healing complications increased across all BMI, except patients with a BMI less than or equal to $24 \mathrm{~kg} / \mathrm{m}^{2}$. In the second phase of the same trial, after excluding BMI $>32 \mathrm{~kg} / \mathrm{m}^{2}$ and using a low level of SRL (10 to
$15 \mathrm{ng} / \mathrm{mL}$ ), the complication rate in patients with BMI 28.1 to 32.0 was $33 \%$ in the SRL group as compared with $78 \%$ in phase I of the same trial [8]. Recently, TRANSFORM study excluded patients with BMI greater than 35. The mean BMI of EVL and MPA arm was 25.6 between the two groups. EVL targeting a trough concentration of 3-8 $\mathrm{ng} / \mathrm{ml}$ avoided the increased rates of lymphocele seen previously, though wound healing events/complications were still slightly higher as compared to MPA (19.8\% vs.16.2\%) [53]. Later indepth analysis of TRANSFORM data by Tedesco et al. found no significant association when wound healing complications were compared with mean EVL concentration during the periods from day 4 to week 4 , day 4 to month 2 , and day 4 to month 12 [69].

4.5. Uremia and Renal Dysfunction. Unlike other surgeries done on patients with normal renal functions, kidney transplant patients have preceding uremia, which has a negative impact on wound healing. There are over 100 uremic toxins in patients with end-stage renal disease [70]. It has been shown that uremia impairs fibroblast proliferation and hydroxyproline level [71-74]. Other factors that make a chronic kidney disease patient prone to impaired wound healing include uremic itch, calcemic uremic arteriopathy, malnutrition, edema, and propensity for infections [75]. Cadaveric transplantation being an unplanned event, it is always difficult to ensure adequate dialysis in the preceding past. Live transplantation being a preplanned event always provides the opportunity to provide adequate dialysis in the preceding month.

4.6. Age. Increasingly a greater number of elderly populations is being transplanted nowadays. Age-related skin changes affect all stages of wound healing [76]. Platelets' adherence to injured endothelium and release of various cytokines (PDGF, TGF) is enhanced in the elderly population [77]. As a result, inflammatory cells are recruited to the wound healing site. There is early infiltration of neutrophils but delayed infiltration of monocytes-macrophages compared to the young population. Macrophages played an important role in wound healing, and their late infiltration may be one reason for impaired wound healing in this population [78]. In rat models, angiogenesis is reduced in aged rats [79] and has reduced macrophage content [80]. Wound remodeling may be impaired due to reduced collagen turnover and increased fibroblast senescence [76]. There is a paucity of aging data and its effect on impaired wound healing in the kidney transplant population.

4.7. Diabetes. There is paucity of data on the impact of diabetes on wound healing complications in kidney transplantation. In diabetics, there is a delayed response to injury due to impaired functioning of the leukocytes and fibroblast and reduced insulin in the face of hyperglycemia [81]. Experimental studies in the acute diabetic pig model have shown that reduced insulin-like growth factors rather than hyperglycemia resulted in impaired wound healing [82]. 
Another in vitro study on mice showed that diabetic fibroblasts show selective impairments in cellular responses needed for tissue repair, impaired VEGF production, and impaired response to hypoxia [83]. Osmotic diuresis and catabolism associated with uncontrolled diabetes may also impair wound healing $[84,85]$. Keeping these facts in mind, it is crucial to have meticulous diabetes control pre, peri, and postoperative time for better wound healing.

4.8. Alcohol. Both acute alcohol intoxication and chronic alcoholism impaired wound healing. Critical alcohol consumption reduces proinflammatory cytokines in the face of inflammatory challenges. It also reduces the infiltration of neutrophils and their phagocytic function at the site of inflammation. This impairs the initial inflammatory response and increases the risk of infection [86, 87]. Alcohol also affects the proliferative phase of wound healing. It has been shown in experimental studies that epithelial healing, new blood vessel formation, collagen production, and wound closure are all reduced even with a single dose of alcohol $[88,89]$. Single ethanol exposure in both in vitro and in vivo settings before the injury can cause a significant decrease in wound breaking strength due to impaired fibroblast function and collagen production [90].

4.9. Smoking. Smoking has been shown to affect the migration of white blood cells to the site of inflammation. There is a reduced number of monocytes and macrophages at the wound sites, while the ability of neutrophils to kill bacteria is also impaired. Smoking affects lymphocytes and natural killer cells' functional ability at the site of inflammation [91, 92]. Smoking impairs epithelization and reduces the ability of fibroblasts to migrate and proliferate, resulting in an impaired proliferative phase of wound healing [91]. Nicotine causes peripheral vasoconstriction and increases the blood's viscosity through reduced fibrinolytic activity and increased platelet aggregations. Carbon monoxide in smoker binds hemoglobin more efficiently and reduces oxygen saturation. These factors result in reduced oxygen and blood supply leading to impaired wound healing $[91,93]$. It has been shown that quitting smoking improves wound healing and reduces infection [94]. It is important to stop smoking six weeks before surgery, including transplantation [95].

4.10. Protein-Energy Malnutrition. Malnutrition of dialysis patients is multifactorial. Inadequate protein and calorie intake, loss of appetite, inflammation, loss of residual renal function, inadequate dialysis, insulin resistance, and superimposed comorbid conditions are the various causes for malnutrition [96-98]. The prevalence of malnutrition in dialysis patients has been reported between $18 \%$ and $56 \%$ $[99,100]$. The recommended dietary protein intake for clinically stable maintenance hemodialysis patients is $1.2 \mathrm{~g} /$ $\mathrm{kg}$ body weight/day. At least $50 \%$ of the dietary protein should be of high biological value. Dietary protein intake for patients on peritoneal dialysis who are clinically stable is 1.2 to $1.3 \mathrm{~g} / \mathrm{kg}$ body weight/day [101].

Protein is essential for wound healing, capillary formation, fibroblast proliferation, proteoglycan, and collagen synthesis. It is also necessary for optimal phagocytic activities of leukocytes. As a result, protein-energy malnutrition (PEM) results in impaired wound healing and reduced phagocytic infection [102]. Collagen is the major protein component of connective tissue and is composed primarily of glycine, proline, and hydroxyproline. Collagen synthesis requires hydroxylation of lysine and proline and cofactors such as ferrous iron and vitamin C. Impaired wound healing results from deficiencies in any of these cofactors [103]. KDOQI guidelines also suggested that nPCR should be between 1.0 and $1.2 \mathrm{~g} / \mathrm{kg} / \mathrm{d}$, and serum albumin should be equal to or greater than $4.0 \mathrm{~g} / \mathrm{dL}$ [104]. It is important to achieve these parameters before any surgical intervention to avoid wound healing complications.

\section{Review of Randomized Control Trials on mTOR-I}

In NEVERWOUND study, a randomized control trial, wound healing complications included fluid collection, including hematoma and lymphocele, prolonged lymphatic drainage (lymphorrhea), wound dehiscence, wound infection, urine leak, and incisional hernia [18]. Ueno et al. [105] described wound healing complications such as wound dehiscence, wound infection, incisional hernia, lymphorrhea, fluid collections, peri graft hematoma, and urine leak. All fluid collections were diagnosed by either ultrasound or computed tomography (CT). We reviewed all randomized control trials which looked at these wound healing complications.

With the advent of SRL in 1972 [106], SRL was being evaluated since earlier 1996 in randomized control trials [107]. Unfortunately, not all trials looked at wound healing complications or lymphocele formations as a primary or secondary outcome. Some of the initial randomized control trials reported more wound infections, wound healing complications, and lymphocele formation [108-111]. Earlier case series and retrospective data also point to wound healing complications and lymphocele formation $[52,68,112]$. Various randomized control trials from 1999 to 2017 over the last 2 decades looked at either wound healing complications or lymphocele formations $[1,7,8,11,15,16,108-111,113-127]$. Most of the earlier trials reported a positive association of SRL with either wound healing complications or lymphocele formations. However, most of these trials used a loading dose ranging from $6 \mathrm{mg}$ to $30 \mathrm{mg}$ and maintained very high trough level of 10-30 ng/mL [1, 5, 7, 12, 108-111, 113, 115, 116, 118-125]. In RCT by Kandasamy et al. [116], wound healing complications were significantly reduced when loading dose was avoided in the second phase of the trial. Various randomized control trials which compared low-dose SRL with high-dose SRL reported a smaller number of wound healing complications in low-dose SRL $[6,8,9,12-14,110,113,116,117]$ numerically. Vitko et al. compared low-dose SRL $(1.5 \mathrm{mg}$ 
first dose followed by $0.5 \mathrm{mg}$ once a day vs. $6 \mathrm{mg}$ first dose followed by $2 \mathrm{mg}$ per day) and found a significantly lower incidence of lymphocele $(p=0.022)$ [11]. In a recent RCT, SRL was used with extended-release tacrolimus (ER-TAC). SRL-ER TAC was compared with MMF-TAC. SRL level was kept at $3-5 \mathrm{ng} / \mathrm{mL}$, and no difference was found between the two groups in terms of wound healing and lymphocele formation [127]. Table 3 shows summaries of randomized control trials which looked into wound healing complications and lymphocele formations $[1,7,8,11,12$, $16,108-127]$.

Since earlier 2000 multiple randomized control trials were conducted on EVL $[9,10,13,14,18,69,105,128-139]$ as shown in table [4]. Various studies compared low-dose EVL $(1.5 \mathrm{mg} /$ day) with high-dose EVL ( $3 \mathrm{mg}$ per day). Wound healing complications were numerically higher in the high-dose EVL group [2, 3, 8] but were not statistically significant [129, 130, 135]. In 2013, Cooper et al. [134] showed that the higher blood level of EVR $(>8 \mathrm{ng} / \mathrm{mL})$ was also associated with increased risk (HR, $1.69 ; 95 \% \mathrm{CI}$, $1.20-2.38 ; p=0.002)$ of wound healing complications. Therefore, the initial dose of $1.5 \mathrm{mg}$ seems safer and more reasonable than $3 \mathrm{mg}$. Most studies used level between $3-8 \mathrm{ng} / \mathrm{mL}[10,14,69,131-133,135,138,139]$ without any significant impact on wound healing.

It is important to consider the patient's weight, induction therapy, and combinations of other immunosuppressive medications with mTOR-I. Obesity is an important risk factor that can potentially augment mTOR-I wound healing complications. BMI of $>26$ has significantly been associated with wound healing complications in patients taking SRL (odds ratio 2.498, $p=0.027$ ). The risk is even larger if BMI $>30$ (odds ratio 3.738, $p=0.007$ ) [68]. The risk increases by 1.9-fold for every 5 points of BMI across a range of BMI from 20 to greater than $40 \mathrm{BMI}$ in kidney transplant recipients [64]. In a systemic approach to minimize wound healing complications, multivariate analysis of recipients treated with de novo SRL showed that a BMI more than 30 to $32 \mathrm{~kg} /$ $\mathrm{m}^{2}$ was the most significant variable related to delayed wound healing (OR 3.01, 0.02) and the need to repair a transplant wound surgically (OR 8.05, $p=0.0001$ ) [140]. Kandasamy et al., in the second phase of their trial, showed that exclusion of BMI $>32$ significantly reduced wound healing complications in SRL groups [116]. In the NEVERWOUND study, BMI of $<25 \mathrm{~kg} / \mathrm{m}^{2}$ was identified as a predictor of WHC-free status at 12 months [18]. Besides, consideration of obesity induction with ATG and subsequent use of mTOR-I also increase wound healing complications $[18,62,63]$. Another important fact is that using SRL and MMF may have a synergetic effect on wound healing complications $[1,16,53,54]$. However, few studies on EVL combined with MPS or MMF did not show this synergism. de Fijter et al. [9] compared EVL-MPS with EVL$\mathrm{CNI}$ and found no difference in wound healing complications. Similarly, in the CALLISTO study, no difference was observed in the incidence or severity of wound healing complications in kidney transplant recipients receiving either MMF or EVR as de novo immunosuppressive drug [10]. Nashan et al. [137] also compared EVL-MPS with EVL-CNI and found no difference in wound healing complications in BMI category $\leq 25$ percentile (EVR, 0.9 vs. CNI, $0.8 \%$; $p=0.846)$ and in BMI category of $>25-\leq 50$ percentiles $(2.6$ vs. $1.1 \%, p=0.271)$. However, wound healing complications were significantly higher in $>50-\leq 75$ categories ( 2.0 vs. $0.6 \%$, $p=0.049)$. Majorities of the earlier de novo studies on SRL showed a positive association between wound healing complications and lymphoceles $[1,5,7,12,108-111$, $113,115,116,118-125]$. In contrary to most studies on EVL, which kept trough level 3-8 ng/mL [10, 14, 69, 131-133, 135, $138,139]$, we did not find significance on wound healing or lymphocele formations. These differences could be due to a shorter half-life or higher bioavailability of EVL, or it could be due to loading doses and a very high trough level of $10-30 \mathrm{ng} / \mathrm{mL}$ used in the case of SRL. Avoidance of loading dose $[116,127]$ and use of low-dose SRL have been shown to reduce wound healing complications [115, 127]. No randomized control trial has made a head-to-head comparison between SRL and EVL. An open label RCT is going at the moment, which will compare three arms (EVL-TAC, SRLTAC, and MMF-TAC). The study will be completed by the end of 2021 and will look into safety profile including wound healing complications between SRL and EVR [141].

The thought that delayed administration of mTOR-I may reduce wound complications and delayed graft function was evaluated in a few RCTs. Albano et al. [132] were the first to assess this strategy in 2009. They compared immediate EVL from day 1 with delayed EVL from week five and found no difference in delayed graft function and wound healing complications. Similarly, the CALLISTO study [10] did not find the difference in wound healing complications and delayed graft functions between immediate or delayed use of EVL. These findings were reinforced in 2020 by Manzia et al. [18], who also found no difference in wound healing complications between immediate or delayed use of EVL.

A couple of the recent studies on mTOR-I further increased the insight into using these agents in de novo transplantation. Schäffer et al. [28] in 2018 used ER-TAC with SRL and compared it with ER-TAC and MMF. This group kept trough level 3-5 ng/mL. Wound healing and risk of lymphocele were not significantly different between the two groups. In the TRANSFORM study, the use of EVL aiming for a trough concentration of 3-8 $\mathrm{ng} / \mathrm{ml}$ avoided the increased rates of lymphocele though the wound healing complication were slightly higher [53]. Later on, an in-depth analysis of TRANSFORM data was performed by Tedesco et al. They compared wound healing complications with mean EVL concentration during the periods from day 4 to week 4 , day 4 to month 2 , and day 4 to month 12 . They found no significant association of the mean concentration of EVL with wound healing complications [69]. The ATHENA randomized control trial was published in 2019 and compared three arms consisting of EVR/TAC, EVR/CsA, and MPA/TAC and found no difference in wound healing complications among the three groups [139]. NEVERWOUND study was another RCT published in 2020 which compared immediate use of EVL-CsA-Pred with delayed use and found no difference in wound healing complications and lymphoceles between the two arms [18]. 


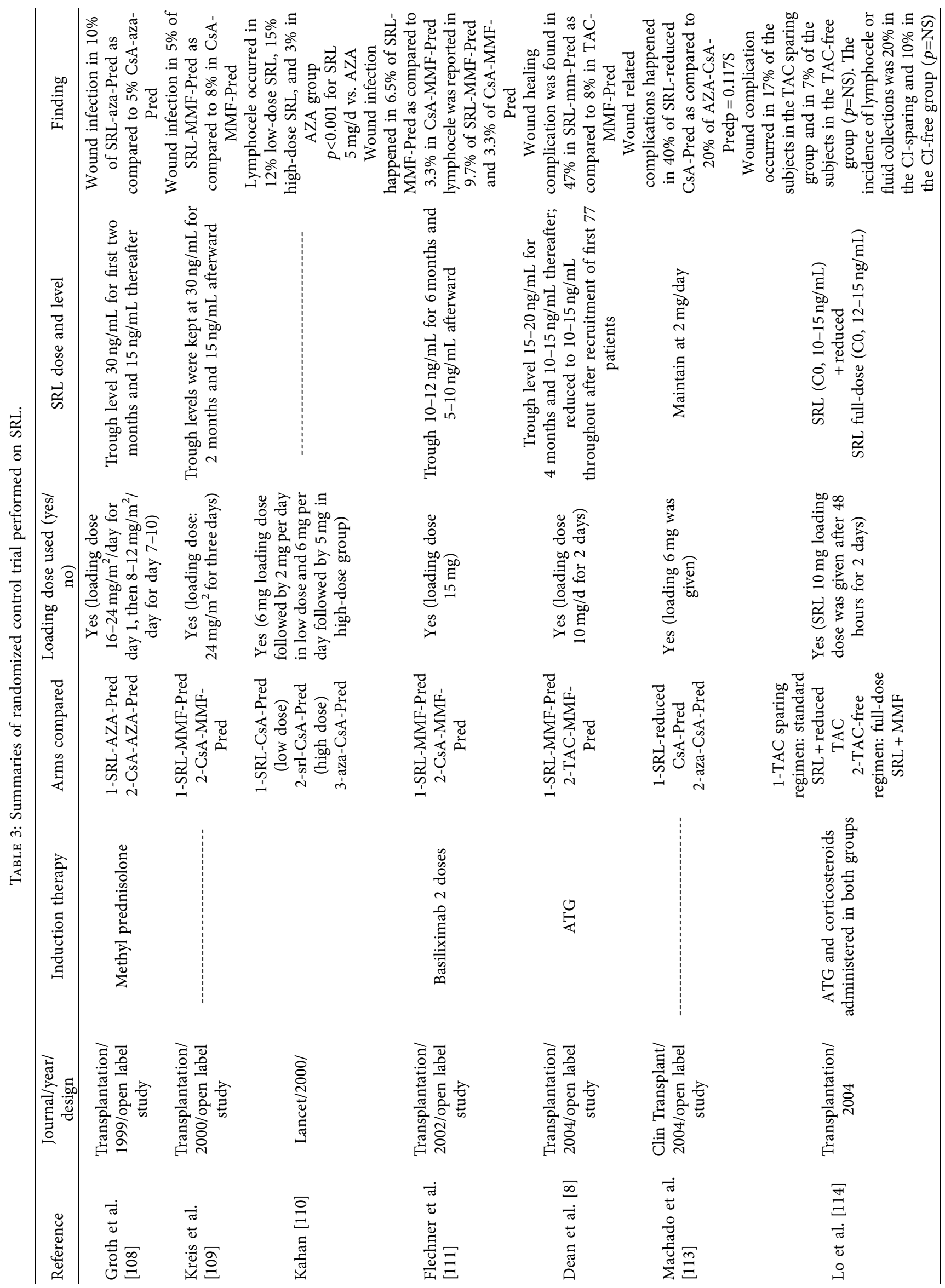




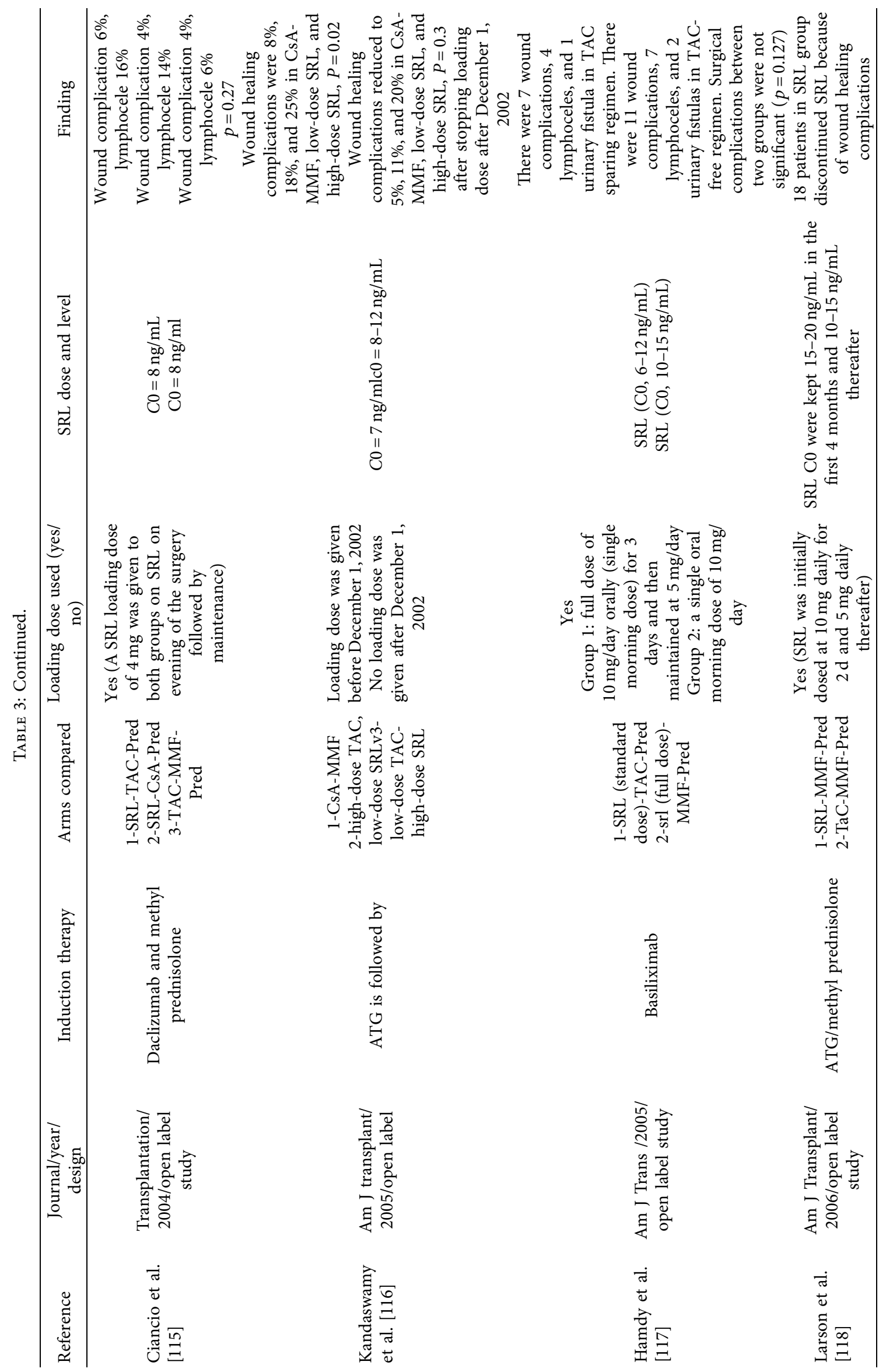




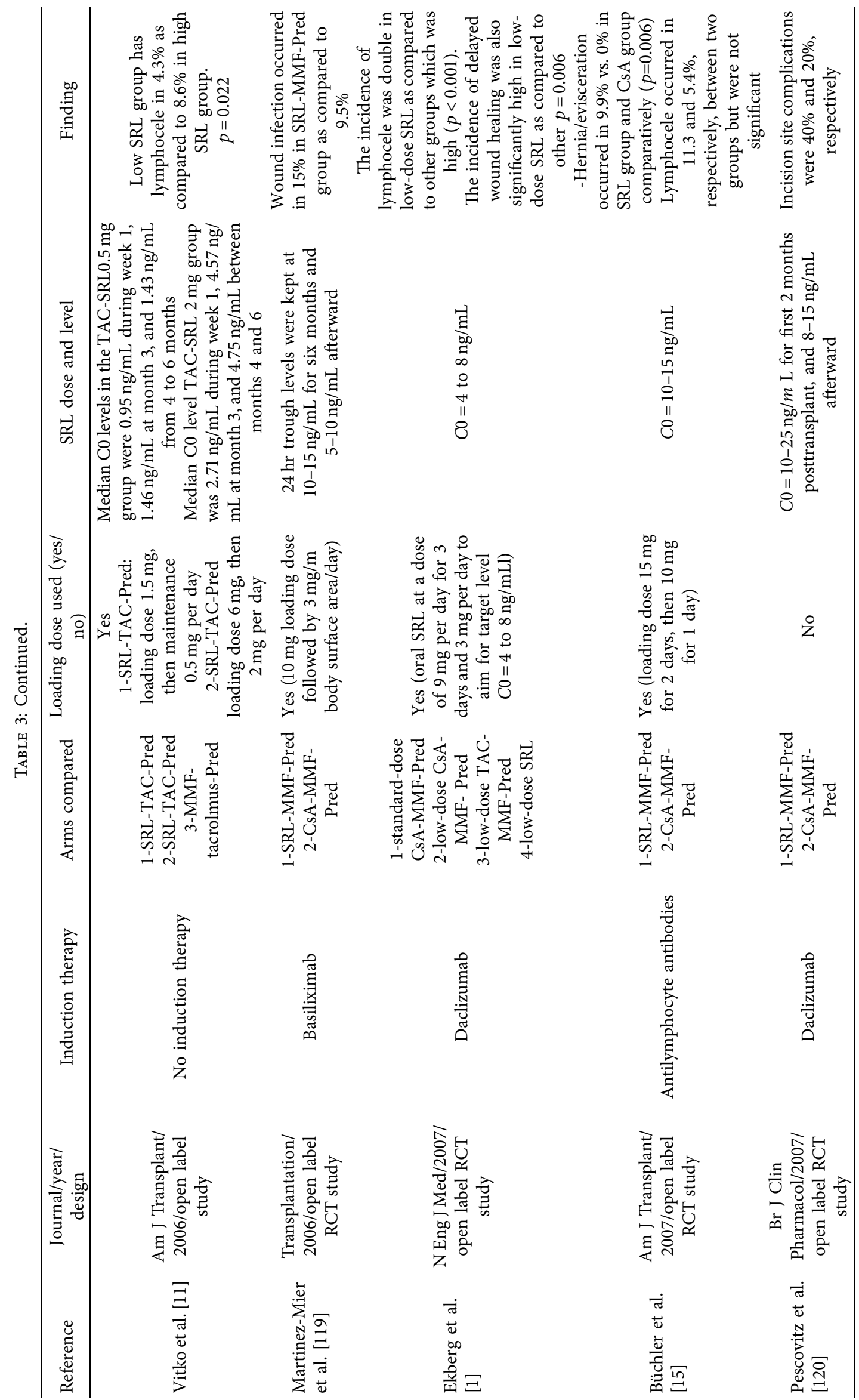




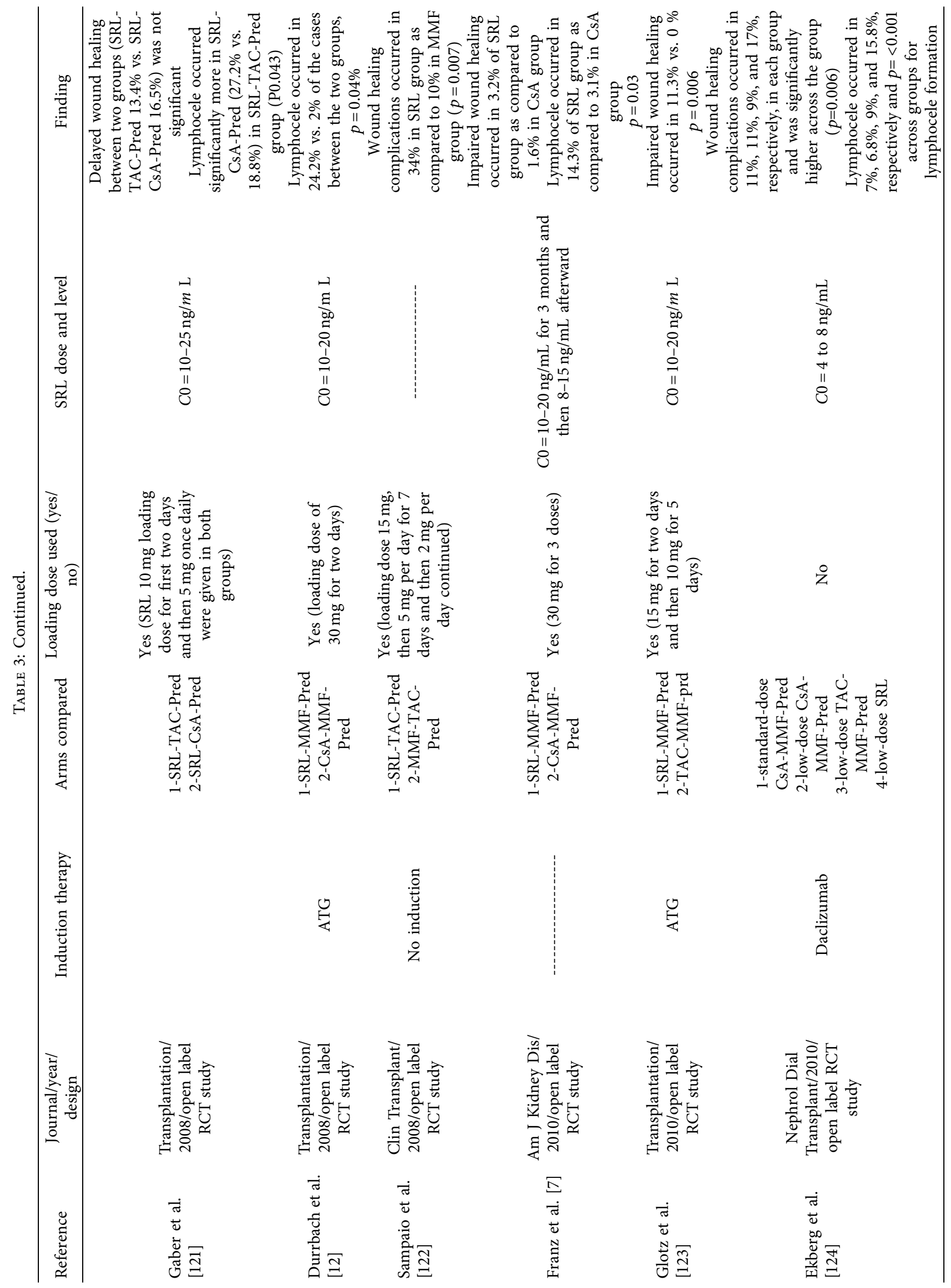




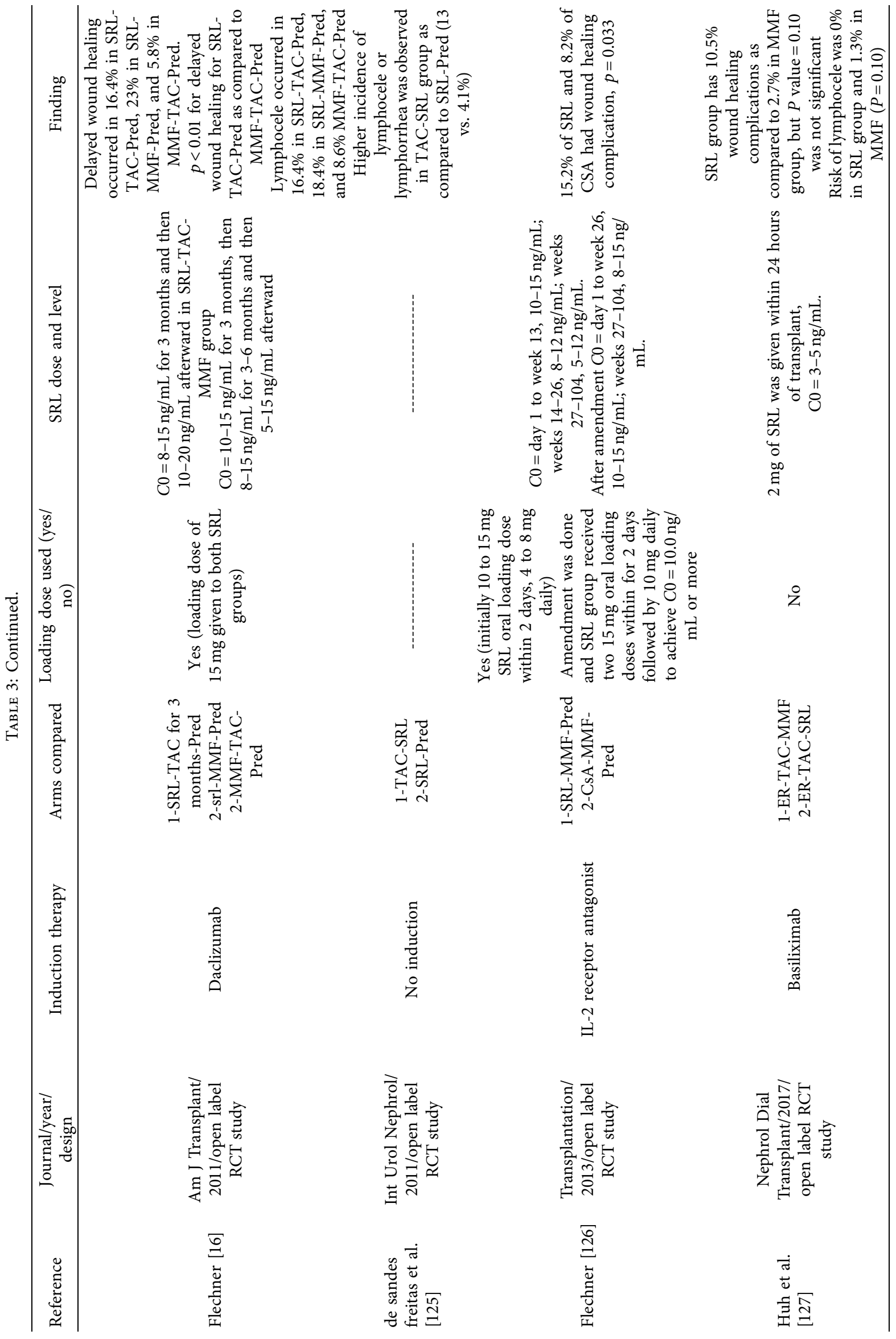




\section{Emergency or Elective Surgery in Patients on mTOR-I}

Clear guidelines for continuing mTOR-I in the wake of any emergency or elective surgery after kidney transplantation are lacking. This is simply due to the lack of randomized control trials. Most of the data available are case reports, retrospective studies, or prospective case series. SRL and obesity have been risking factors for hernia recurrence in liver transplant patients [142]. Different approaches have been reported in the literature for patients undergoing surgery. Scheuerlein et al. switched SRL to calcineurin inhibitors in patients undergoing laparoscopic incisional hernia repair after solid-organ transplantation [143]. On the other side, immunosuppression, including mTOR-I, was maintained postoperatively in patients undergoing laparoscopic incisional hernia repair after solid-organ transplantation and aortic valve replacement in kidney transplant patients $[144,145]$. Hebel et al., in their retrospective analysis of 13 pediatric cardiac patients who underwent surgery, found that only $1 / 13(7.7 \%)$ has wound complications [146]. Schwarz et al. studied six liver transplant recipients who underwent nine major abdominal or thoracic surgical procedures without mTOR-I discontinuation or specific dosage adjustment. They found no evisceration, incisional surgical site infection, or lymphocele [147]. However, one has to bear in mind that patients in this retrospective analysis did not include obese patients and the overall mean SRL trough concentration was $4.8 \mathrm{ng} / \mathrm{mL}$. Campistol et al. made recommendations for minor surgery, major surgery, and emergency surgery in patients on SRL [148]. They kept into consideration nonmodifiable risk factors (age, African American) and modifiable risk factors (obesity $>26 \mathrm{~kg} / \mathrm{m}^{2}$, use of steroids, and use of ATG and anticoagulant) while deciding mTOR-I in the event of surgery. They suggested that no change is required in minor surgery or laparoscopic surgery without risk factors. In major surgery, including those who required chemotherapy, the group recommended holding SRL 5-10 days before the operation and restarting 1-3 months later. They suggested stopping mTOR-I immediately and restarting five days later in emergency surgery.

In the absence of robust data, it is challenging to advise about the withdrawal of mTOR-I in the wake of surgery. While planning for elective surgeries, it is crucial to look for risk factors of wound healing and reduce the dose of mTORI to ensure lesser chances of wound healing complications and prevent rejection at the same time. In emergency surgery in patients with risk factors for wound healing or postoperative wound complications, a decision of withdrawal may be considered.

\section{Way Forward for the Use of mTOR-I}

Minimization of CNI while using mTOR inhibitor provides synergistic immunosuppressive effects and reduces nephrotoxicity. mTOR-I has an antiviral and antitumor effect $[4,6]$. The incidence of cytomegalovirus and BK virus infections in EVL is significantly lower when used with minimized CNI and steroids compared to the combination of MMF [53]. Therefore, it is important to use these agents wisely to achieve their maximum potential benefits and to keep its side effects minimum possible level.

Since the introduction of SRL in 1972 and multiple randomized control trials on EVL since the start of 2000 with the availability of significant amount of evidence, much has been known about these agents. Events of cadaveric kidney transplantation are not planned events and clinicians do not have enough time to optimize nonimmunological risk factors for wound healing complications. In contrast to cadaveric transplantation, live kidney transplantation gives clinicians a chance to optimize the kidney transplant recipients before surgery to ensure a better outcome. Therefore, live kidney transplant recipients should be optimized before the planned surgery. Nonimmunological risk factors should be identified and discussed with the recipients to avoid wound healing complications and optimize recipient and graft survival. Those selected to be a candidate for kidney transplantation should be thoroughly evaluated for wound healing risks. Those with BMI greater than $30 \mathrm{~kg} / \mathrm{m}^{2}$ should be encouraged to lose weight. BMI in lower ranges has been significantly associated with reduced wound healing complications [64]. Detailed smoking history should be obtained, and it is essential to stop smoking six weeks before kidney transplantation [95]. Similarly, alcoholics should be encouraged to quit drinking to reduce wound healing complications. Potential live recipients with a history of diabetes should have optimal diabetes control before transplant to minimize the perceived complications [84]. Patients undergoing renal replacement therapy must have adequate dialysis in the preceding months before transplantation to minimize the effect of uremia on wound healing complications [75]. Clinical evaluation should be performed along with an estimation of protein catabolic rate to identify malnourished patients. These patients should be treated with dietitians to improve their nutritional status $[103,104]$. These patients must have nPCR between 1.0 and $1.2 \mathrm{~g} / \mathrm{kg} / \mathrm{d}$. The serum albumin should be equal to or greater than $4.0 \mathrm{~g} / \mathrm{dL}$ [104]. Figure 2 shows the way forward to minimize wound healing complications.

Previous higher wound healing complications were attributed to higher loading doses of SRL (ranging from $6 \mathrm{mg}$ to $30 \mathrm{mg}$ ) along with higher trough level of $10-30 \mathrm{ng} /$ $\mathrm{mL}[1,5,7,12,108-111,113,115,116,118-125]$. Avoidance of loading has been shown to reduce wound healing complications significantly [116]. Use of low-dose SRL has been shown to reduce incidence of lymphocele significantly when compared with higher dose [11]. Therefore, we suggest to avoid loading dose and keep trough level between $5-10 \mathrm{ng} / \mathrm{mL}[149,150]$ to minimize adverse events and wound healing complications. If one contemplates using SRL with TAC-ER, SRL level can be kept even low at 3-5 ng/mL [127]. Low-dose EVL when compared with high-dose EVL $(1.5 \mathrm{mg} /$ day vs. $3 \mathrm{mg} /$ day $)$ led to numerically a smaller number of wound healing complication $[2,3,8]$. Higher blood level of EVL (>8 ng/ $\mathrm{mL}$ ) has been shown with increased risk (HR, 1.69; 95\% 

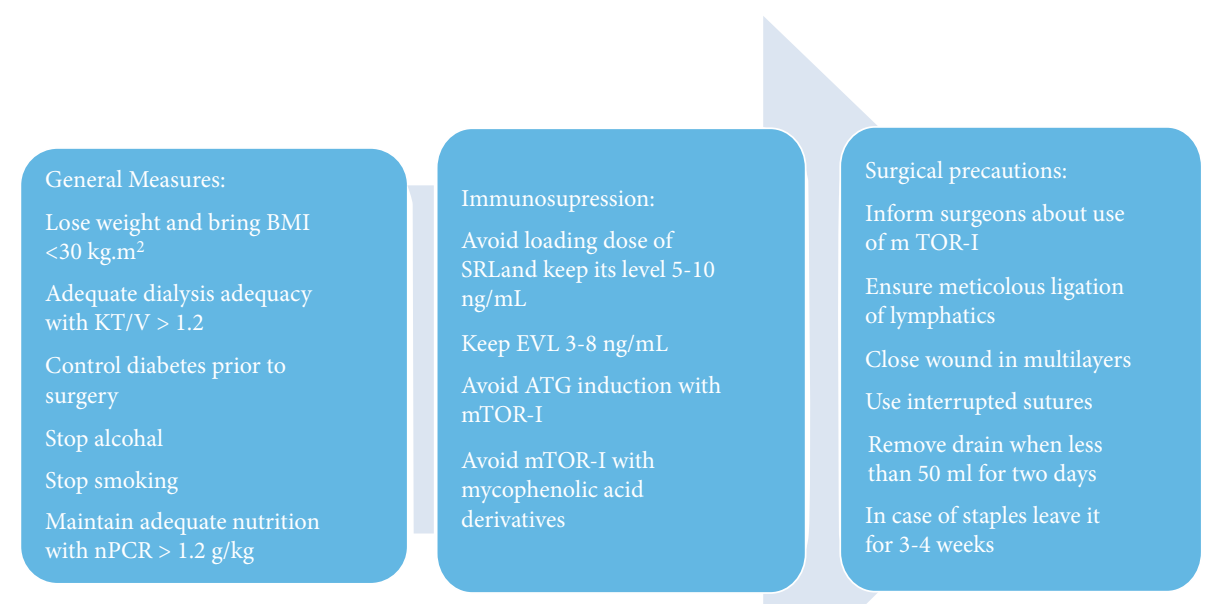

FIgURE 2: Showing the way forward to minimize wound healing.

TABLE 4: Summaries of randomized control trial performed on EVL.

\begin{tabular}{|c|c|c|c|c|c|c|}
\hline Reference & $\begin{array}{c}\text { Journal/year/ } \\
\text { design }\end{array}$ & Induction & Arms compared & EVL dose & EVL level & Finding \\
\hline $\begin{array}{l}\text { Vitko et al. } \\
\text { [13] }\end{array}$ & $\begin{array}{c}\text { Am J Transplant/ } \\
\text { 2004/2 open label } \\
\text { RCT studies }\end{array}$ & $\begin{array}{l}\text { Study 1: without } \\
\text { basiliximab } \\
\text { Study } 2 \text { : with } \\
\text { basiliximab }\end{array}$ & $\begin{array}{c}\text { EVL } 1.5 \text { mg-CsA- } \\
\text { Pred vs. } \\
\text { EVL } 3 \text { mg-CsA- } \\
\text { Pred without } \\
\text { basiliximab } \\
\text { vs. } \\
\text { EVL } 1.5 \text { mg-CsA- } \\
\text { Pred vs. } \\
\text { EVL } 3 \text { mg-CsA-P } \\
\text { ped with } \\
\text { basiliximab }\end{array}$ & $\begin{array}{c}\text { Both arms, two } \\
\text { doses of EVL } \\
1.5 \mathrm{mg} / \text { day vs. } \\
3 \mathrm{mg} / \text { day }\end{array}$ & $>3 \mathrm{ng} / m \mathrm{~L}$ & $\begin{array}{l}\text { Study } 1: 15.2 \% \text { had } \\
\text { lymphocele in } \\
1.5 \mathrm{mg} \text { group as } \\
\text { compared to } 6.4 \% \\
\text { in } 3 \mathrm{mg} \text { group } \\
\text { Study } 2: \\
\text { lymphocele was } \\
\text { found in } 10.3 \% \text { in } \\
1.5 \mathrm{mg} \text { EVL group } \\
\text { as compared to } \\
7.2 \% \text { in } 3 \text { mg group } \\
\text { No comment on } p \\
\text { value }\end{array}$ \\
\hline $\begin{array}{l}\text { Vítko et al. } \\
{[128]}\end{array}$ & $\begin{array}{c}\text { Am J Transplant/ } \\
\text { 2005/double blind } \\
\text { RCT study }\end{array}$ & - & $\begin{array}{l}\text { 1-EVL-CsA-Pred } \\
\text { 2- EVL-CsA-Pred } \\
\text { 3-MMF-CsA-Pred }\end{array}$ & $\begin{array}{l}1.5 \mathrm{mg} / \text { day } \\
3 \mathrm{mg} / \text { day }\end{array}$ & $>3 \mathrm{ng} / m \mathrm{~L}$ & $\begin{array}{l}\text { Lymphocele } \\
\text { occurred in } 9 \% \text { in } \\
\text { EVL } 1.5 \text { mg-CsA- } \\
\text { Pred as compared } \\
12 \% \text { in EVL } 3 \text { mg- } \\
\text { CsA-Pred group } \\
\text { and } 4 \% \text { in MMF- } \\
\text { CsA-Pred ( } p \text { value } \\
\text { not significant) }\end{array}$ \\
\hline $\begin{array}{l}\text { Lorber et al. } \\
\text { [129] }\end{array}$ & $\begin{array}{c}\text { Transplantation/ } \\
\text { 2005/open label } \\
\text { RCT study }\end{array}$ & $\begin{array}{c}\text { Methyl } \\
\text { prednisolone }\end{array}$ & $\begin{array}{l}\text { 1-EVL-CsA-Pred } \\
\text { 2- EVL-CsA-Pred } \\
\text { 3-MMF-CsA-Pred }\end{array}$ & $\begin{array}{c}1.5 \mathrm{mg} / \text { day } \\
3 \mathrm{mg} / \text { day }\end{array}$ & $>3 \mathrm{ng} / m \mathrm{~L}$ & $\begin{array}{c}\text { Lymphocele } \\
\text { occurred in EVL } \\
1.5 \mathrm{mg} \text { group in } \\
16.1 \%, 18.6 \% \text { in } \\
\text { EVL } 3 \mathrm{mg} \text {, and } \\
12.2 \% \text { in MMF- } \\
\text { CsA-Pred group. } \\
p \text { value was } \\
\text { insignificant }\end{array}$ \\
\hline
\end{tabular}


TABle 4: Continued.

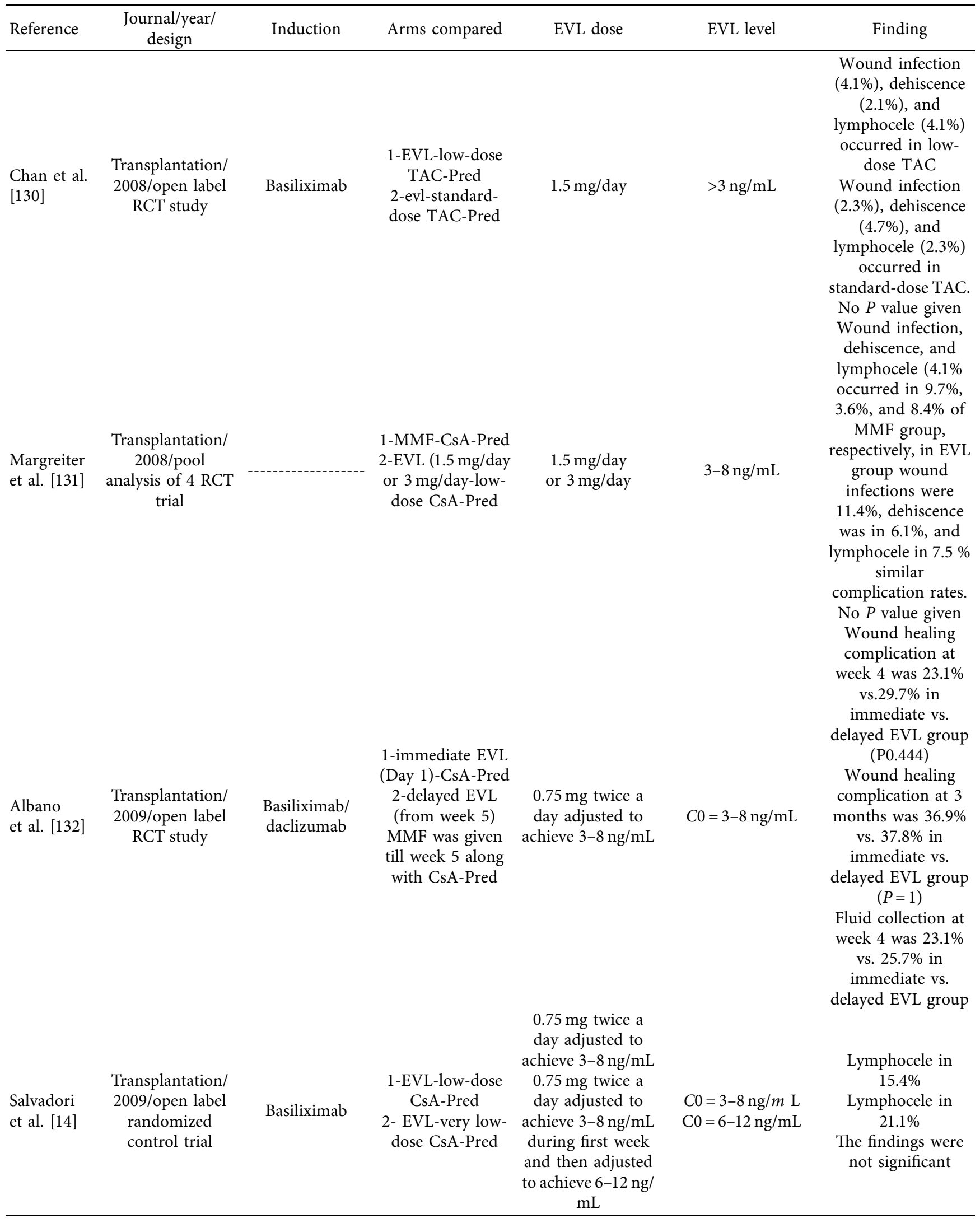


TABle 4: Continued.

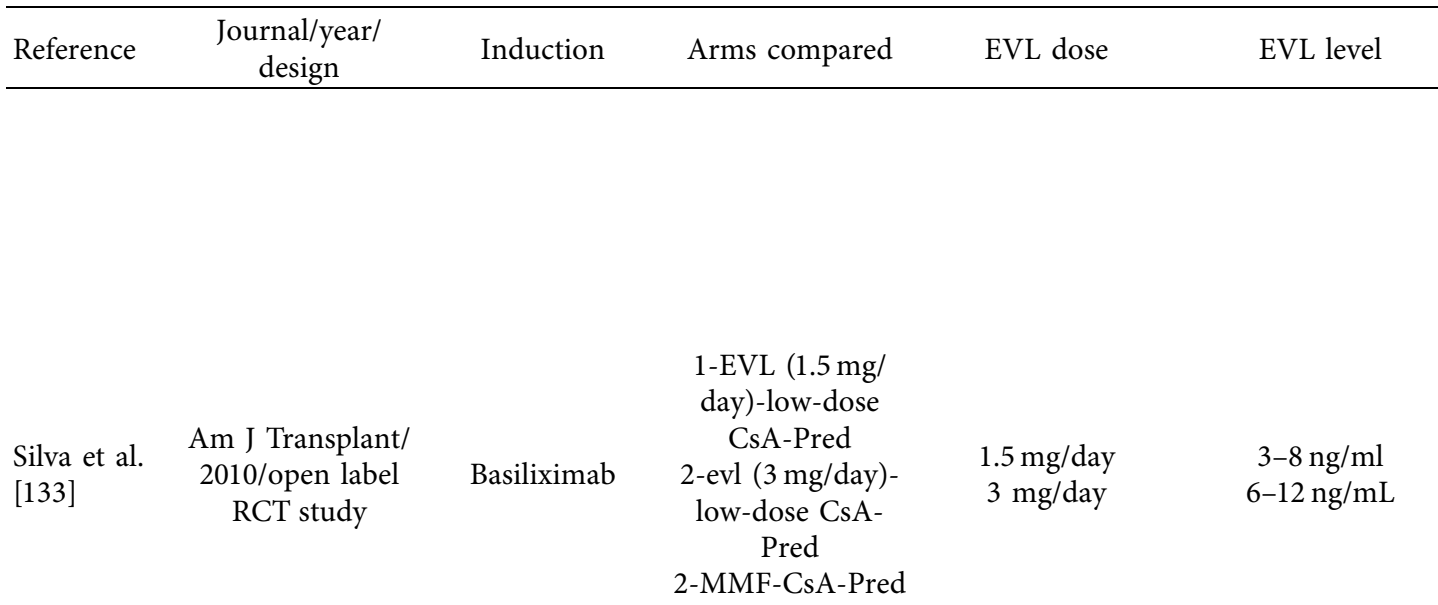

Dantal et al. Transpl Int/2010/ [10] open label RCT study

Clin Transplant/

Cooper

et al. [134] 2013/pool analysis of three RCT studies

Cibrik et al. Transplantation/ [135] 2013/open label RCT study
Basiliximab/ daclizumab

Basiliximab 1-immediate EVL

(Day 1)-CsA-Pred 2-delayed EVL (from week 5) MMF was given till week 5 along with CsA-Pred

1-EVL (1.5 mg/ day)-CsA-Pred

2-evl (3 mg/day)CsA-Pred

3-MMF-CsA-

1.5 or $3.0 \mathrm{mg}$ or

MPA, with CsA and steroids

1-EVL (3-8 ng/ $\mathrm{ml})+$ reduced exposure

CsA + Pred

2- EVL (6-12 ng/ $\mathrm{ml})+$ reduced exposure

CsA + Pred

3-MMF-standard

CsA + Pred

\section{$0.75 \mathrm{mg}$ twice a day adjusted to \\ $\mathrm{CO}=3-8 \mathrm{ng} / \mathrm{mL}$} achieve $3-8 \mathrm{ng} / \mathrm{mL}$ in both the groups

$$
1.5 \mathrm{mg} / \text { day }
$$$$
3 \mathrm{mg} / \text { day }
$$

Dose was adjusted

to get level 3-8 ng/ $\mathrm{mL}$

Dose was adjusted

to get level

6-12 ng/mL
Finding

Lymphocele occurred in $6.6 \%$,

$11.2 \%$, and $5.1 \%$ in low-dose EVL,

high-dose EVL, and MMF, respectively. Impaired wound healing occurred in $1.8 \%, 4 \%$, and $1.1 \%$ in low-dose EVL, high-dose EVL, and MMF, respectively Wound dehiscence occurred in $1.5 \%$, $3.2 \%$, and $1.5 \%$ in low-dose EVL, high-dose EVL, and MMF, respectively No comment on $p$ value for either of the finding Wound healing complications were $40 \%$ immediate group and $37.8 \%$ delayed group at 12 months respectfully $(p=0.86 \mathrm{NS})$

Wound healing complications were $36.9 \%$ in immediate group and $33.8 \%$ in delayed group at 12 months respectfully ( $p$-NS)

Wound healing complication was $16.6 \%$ in $1.5 \mathrm{mg} /$ day in EVL as compared to $14.3 \%$ in MMF $(p=0.255)$

But, it was $21.8 \%$ in EVL $3 \mathrm{mg} /$ day significantly higher in MMF group $(p<0.001)$

Rare wound healing events of $0.4 \%$ in EVL (3-8 $\mathrm{ng} / \mathrm{mL}$ ), $0.7 \%$ in EVL

(6-12 ng/mL), and $1 \%$ in MMF group 
TABle 4: Continued.

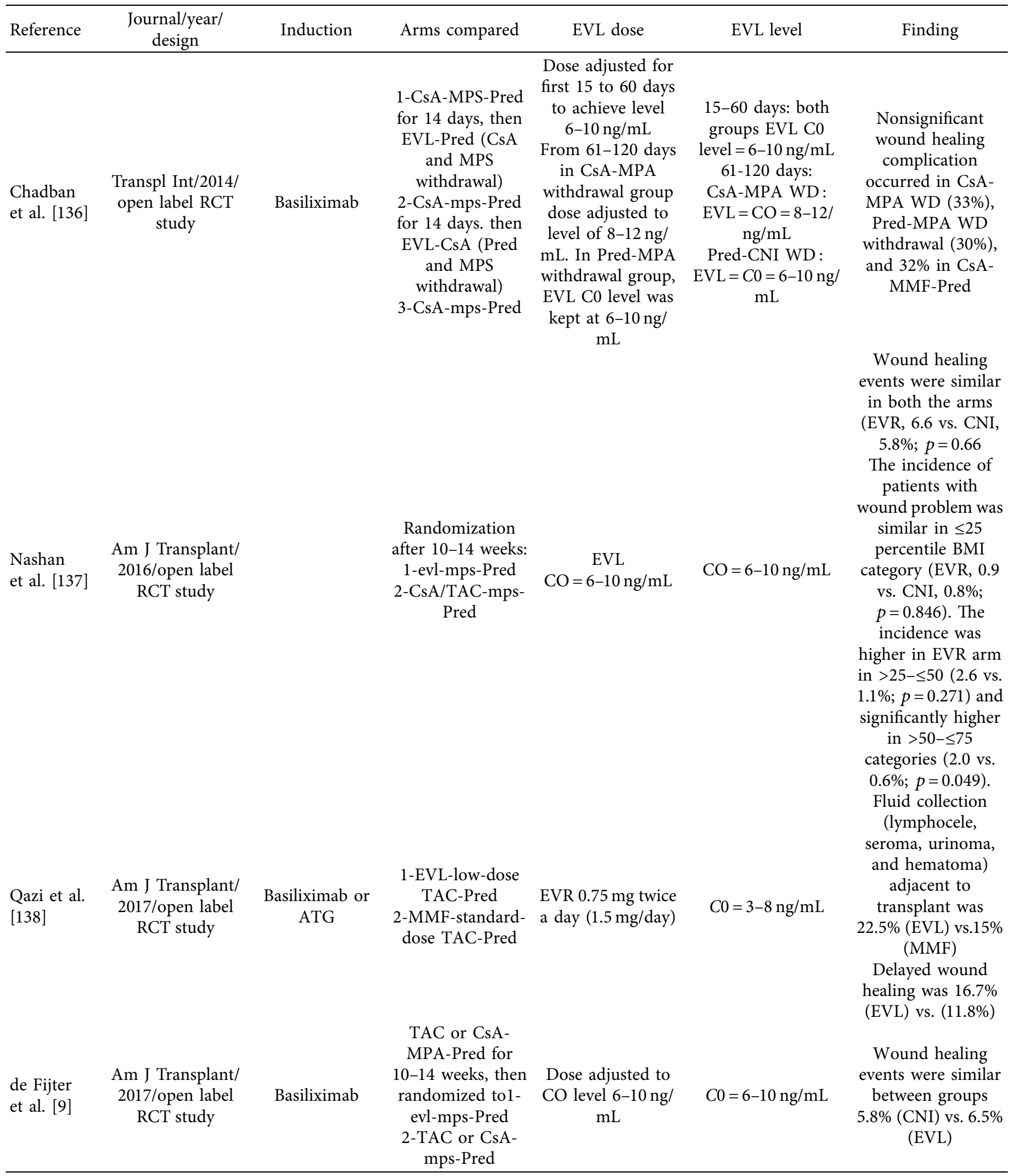


TABLE 4: Continued.

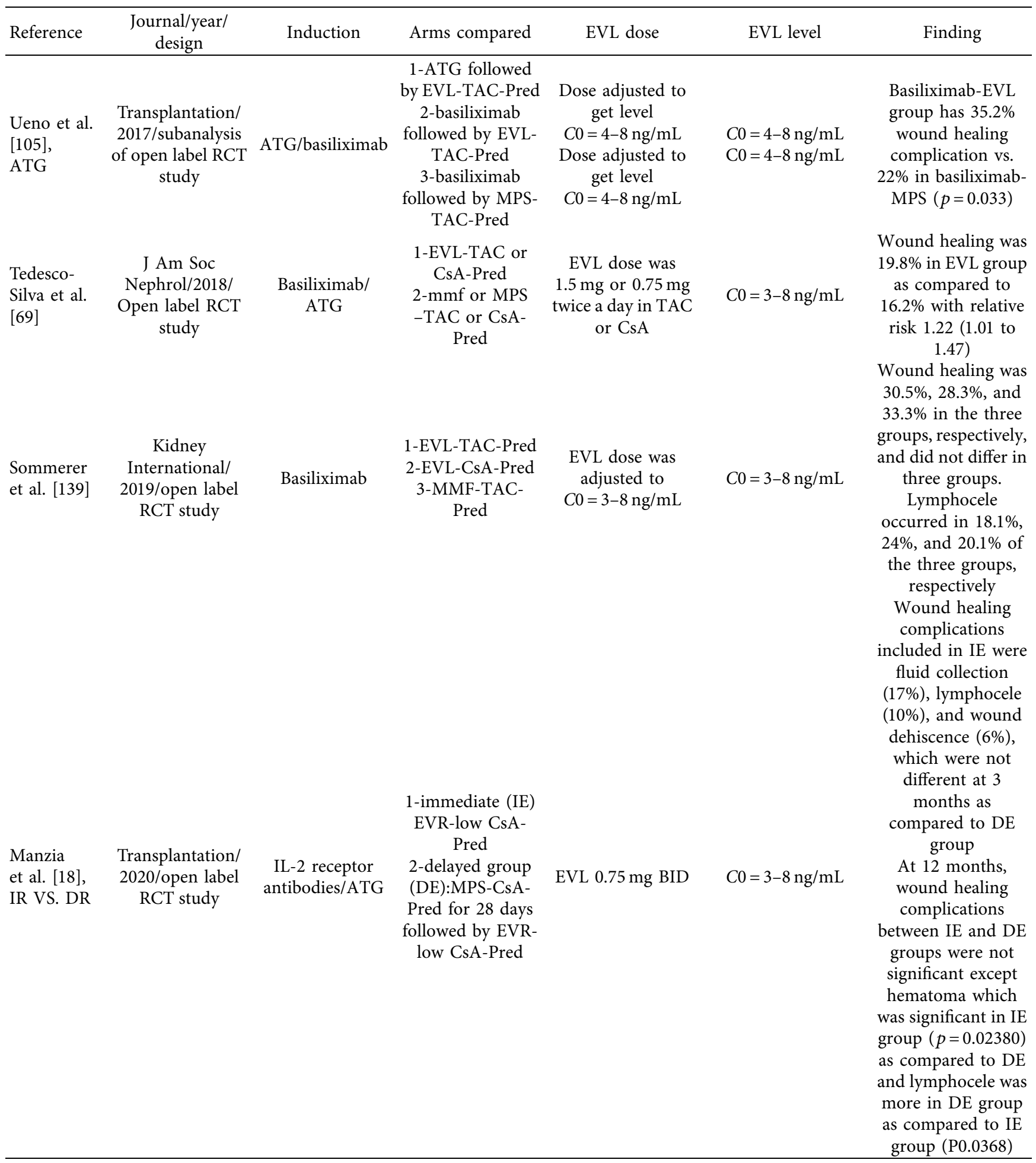

CI, 1.20-2.38; $p=0.002$ ) [134]. Therefore, we suggest EVL level to be kept between $3-8 \mathrm{ng} / \mathrm{mL}$ $[10,14,69,131-133,135,138,139]$. ATG induction in patients with mTOR-I should be avoided to reduce wound healing complications $[18,62,63]$. Since most candidates for mTOR-I are of low immunological risk, induction with basiliximab will be a reasonable option. The combination of SRL with MMF has synergetic effects on wound healing, as reported by the SYMPHONY trial. Therefore, mTOR-I, especially SRL, should be avoided with MMF or MPA [1]. Steroid's dose should be minimized to reduce the risk of wound healing [151].

Planning surgery also plays a vital role in preventing wound healing complications. Surgeons must be aware of the potential 
use of mTOR-I in the posttransplant period. Tiong et al. analyzed a systemic approach to minimize wound healing complications in de novo SRL [140]. Their approach included patient selection (body mass index) $[\mathrm{BMI}]<32 \mathrm{~kg} / \mathrm{m}^{2}$, the use of closed suction drains, modifications of surgical technique, and avoidance of a loading dose of SRL. Surgical wound closure was performed via a multilayer closure approach using nonabsorbable interrupted sutures in the fascia. The skin closure was performed through interrupted nonabsorbable monofilament sutures. The drains were removed after 2-3 weeks or when drain volume was less than $50 \mathrm{ml}$ for two days. The sutures were usually left for three weeks in the majority of patients. Using this approach, a significant reduction was found in cumulative wound complications $(7.8 \%$ vs. $19.6 \%, p<0.007)$ and lymphocele $(22.3 \%$ vs. $47.1 \%, p<0.0001)$ as compared to the historical cohort [140], leaving staples for 3-4 weeks and draining till drainage minimizes wound dehiscence and collection [148]. Ligation of lymphatic meticulously, peritoneal fenestration, and minimizing dissection will reduce lymphocele formation [151].

\section{Conclusion}

mTOR-I can be used immediately after kidney transplantation. Loading doses and high trough levels for SRL lead to more wound healing complications and should be avoided. EVL trough level of 3-8 ng/mL maintains its efficacy and avoids most adverse events, including wound healing complications. Induction with ATG may be avoided. mTOR-I should be used with low-dose CNI, and its combination with mycophenolic acid derivatives should be avoided. Patients with BMI $\geq 30 \mathrm{~kg} / \mathrm{m}^{2}$ should be encouraged to lose weight before surgery. Adequate nutrition, cessation of smoking and alcoholism, controlling diabetes, and adequate dialysis before transplant surgery can minimize wound healing complications. Surgical wound closure in multilayers using interrupted suture, meticulous ligation of lymphatics, leaving staples for 3-4 weeks, and using close suction drain decrease wound healing complications [152] (Table 4).

\section{Abbreviations}

\section{Pred: Prednisolone}

mTOR-I: Mammalian target of rapamycin inhibitors

ATG: Antithymocyte globulin

BMI: Body mass index

CNI: Calcineurin inhibitor

CsA: Cyclosporine

ER-TAC: Extended-release tacrolimus

MMF: Mycophenolate Mofetil

MPA: Mycophenolic acid

SRL: $\quad$ Sirolimus

TAC: Tacrolimus.

\section{Data Availability}

This is a review article with no data.

\section{Conflicts of Interest}

The authors declare that they have no conflicts of interest.

\section{Acknowledgments}

The corresponding author acknowledges all the coauthors for their valuable input and drafting of this manuscript.

\section{References}

[1] H. Ekberg, H. Tedesco-Silva, A. Demirbas et al., "Reduced exposure to calcineurin inhibitors in renal transplantation," New England Journal of Medicine, vol. 357, no. 25, pp. 2562-2575, 2007.

[2] H. Pilmore, H. Dent, S. Chang, S. P. McDonald, and S. J. Chadban, "Reduction in cardiovascular death after kidney transplantation," Transplantation, vol. 89, no. 7, pp. 851-857, 2010.

[3] E. A. Engels, R. M. Pfeiffer, J. F. Fraumeni Jr et al., "Spectrum of cancer risk among US solid organ transplant recipients," JAMA, vol. 306, no. 17, pp. 1891-1901, 2011.

[4] E. L. Yanik, K. Siddiqui, and E. A. Engels, "Sirolimus effects on cancer incidence after kidney transplantation: a metaanalysis," Cancer Medicine, vol. 4, no. 9, pp. 1448-1459, 2015.

[5] S. Eckl, C. Heim, S. Abele-Ohl et al., "Combination of clopidogrel and everolimus dramatically reduced the development of transplant arteriosclerosis in murine aortic allografts," Transplant International: Official Journal of the European Society for Organ Transplantation, vol. 23, pp. 959-966, 2010.

[6] H. Tedesco-Silva, C. Felipe, A. Ferreira et al., "Reduced incidence of cytomegalovirus infection in kidney transplant recipients receiving everolimus and reduced tacrolimus doses," American Journal of Transplantation, vol. 15, no. 10, pp. 2655-2664, 2015.

[7] S. Franz, A. Regeniter, H. Hopfer, M. Mihatsch, and M. Dickenmann, "Tubular toxicity in sirolimus- and cyclosporine-based transplant immunosuppression strategies: an ancillary study from a randomized controlled trial," American Journal of Kidney Diseases, vol. 55, no. 2, pp. 335-343, 2010.

[8] P. G. Dean, W. J. Lund, T. S. Larson et al., "Wound-healing complications after kidney transplantation: a prospective, randomized comparison of sirolimus and Tacrolimus1," Transplantation, vol. 77, no. 10, pp. 1555-1561, 2004.

[9] J. W. de Fijter, H. Holdaas, O. Øyen et al., "Early conversion from calcineurin inhibitor- to everolimus-based therapy following kidney transplantation: results of the randomized ELEVATE trial," American Journal of Transplantation, vol. 17, no. 7, pp. 1853-1867, 2017.

[10] J. Dantal, F. Berthoux, M.-C. Moal et al., "Efficacy and safety of de novo or early everolimus with low cyclosporine in deceased-donor kidney transplant recipients at specified risk of delayed graft function: 12-month results of a randomized, multicenter trial," Transplant International, vol. 23, no. 11, pp. 1084-1093, 2010.

[11] S. Vitko, Z. Wlodarczyk, L. Kyllönen et al., "Tacrolimus combined with two different dosages of sirolimus in kidney transplantation: results of a multicenter study," American Journal of Transplantation, vol. 6, no. 3, pp. 531-538, 2006.

[12] A. Durrbach, L. Rostaing, L. Tricot et al., "Prospective comparison of the use of sirolimus and cyclosporine in 
recipients of a kidney from an expanded criteria donor," Transplantation, vol. 85, no. 3, pp. 486-490, 2008.

[13] S. Vitko, H. Tedesco, J. Eris et al., "Everolimus with optimized cyclosporine dosing in renal transplant recipients: 6month safety and efficacy results of two randomized studies," American Journal of Transplantation, vol. 4, no. 4, pp. 626-635, 2004.

[14] M. Salvadori, M. P. Scolari, E. Bertoni et al., "Everolimus with very low-exposure cyclosporine a in de novo kidney transplantation: a multicenter, randomized, controlled trial," Transplantation, vol. 88, no. 10, pp. 1194-1202, 2009.

[15] M. Büchler, S. Caillard, S. Barbier et al., "Sirolimus versus cyclosporine in kidney recipients receiving thymoglobulin, mycophenolate mofetil and a 6-month course of steroids," American Journal of Transplantation: Official Journal of the American Society of Transplantation and the American Society of Transplant Surgeons, vol. 7, pp. 2522-2531, 2007.

[16] S. M. Flechner, M. Glyda, S. Cockfield et al., "The ORION study: comparison of two sirolimus-based regimens versus tacrolimus and mycophenolate mofetil in renal allograft recipients," American Journal of Transplantation, vol. 11, no. 8, pp. 1633-1644, 2011.

[17] S. Sandrini, G. Setti, N. Bossini et al., "Steroid withdrawal five days after renal transplantation allows for the prevention of wound-healing complications associated with sirolimus therapy," Clinical Transplantation, vol. 23, pp. 16-22, 2009.

[18] T. M. Manzia, M. Carmellini, P. Todeschini et al., "A 3month, multicenter, randomized, open-label study to evaluate the impact on wound healing of the early (vs delayed) introduction of everolimus in de novo kidney transplant recipients, with a follow-up evaluation at 12 Months after transplant (NEVERWOUND study)," Transplantation, vol. 104, no. 2, pp. 374-386, 2020.

[19] M. Waldner, D. Fantus, M. Solari, and A. W. Thomson, "New perspectives on mTOR inhibitors (rapamycin, rapalogs and TORKinibs) in transplantation," British Journal of Clinical Pharmacology, vol. 82, no. 5, pp. 1158-1170, 2016.

[20] D. Fantus and A. W. Thomson, "Evolving perspectives of mTOR complexes in immunity and transplantation," American Journal of Transplantation, vol. 15, no. 4, pp. 891-902, 2015.

[21] K. Mahalati and B. D. Kahan, "Clinical pharmacokinetics of sirolimus," Clinical Pharmacokinetics, vol. 40, no. 8, pp. 573-585, 2001.

[22] D. J. A. R. Moes, H.-J. Guchelaar, and J. W. de Fijter, "Sirolimus and everolimus in kidney transplantation," Drug Discovery Today, vol. 20, no. 10, pp. 1243-1249, 2015.

[23] A. Gosain and L. A. DiPietro, "Aging and wound healing," World Journal of Surgery, vol. 28, no. 3, pp. 321-326, 2004.

[24] S. Guo and L. A. Dipietro, "Factors affecting wound healing," Journal of Dental Research, vol. 89, no. 3, pp. 219-229, 2010.

[25] A. Azzola, A. Havryk, P. Chhajed et al., "Everolimus and mycophenolate mofetil are potent inhibitors of fibroblast proliferation after lung transplantation1," Transplantation, vol. 77, no. 2, pp. 275-280, 2004.

[26] Y. Akselband, M. W. Harding, and P. A Nelson, "Rapamycin inhibits spontaneous and fibroblast growth factor betastimulated proliferation of endothelial cells and fibroblasts," Transplantation Proceedings, vol. 23, pp. 2833-2836, 1991.

[27] D. O. Bates and R. O. P Jones, "The role of vascular endothelial growth factor in wound healing," The International Journal of Lower Extremity Wounds, vol. 2, no. 2, pp. 107$120,2003$.
[28] M. R. Schäffer, P. A. Efron, F. J. Thornton, K. Klingel, S. S. Gross, and A. Barbul, "Nitric oxide, an autocrine regulator of wound fibroblast synthetic function," The Journal of Immunology, vol. 158, pp. 2375-2381, 1997.

[29] P. A. Kelly, S. A. Gruber, F. Behbod, and B. D. Kahan, "Sirolimus, a new, potent immunosuppressive agent," Pharmacotherapy: The Journal of Human Pharmacology and Drug Therapy, vol. 17, pp. 1148-56, 1997.

[30] M. Schäffer, R. Schier, M. Napirei, S. Michalski, T. Traska, and R. Viebahn, "Sirolimus impairs wound healing," Langenbeck's Archives of Surgery, vol. 392, pp. 297-303, 2007.

[31] R. Humar, F. N. Kiefer, H. Berns, T. J. Resink, and E. J. Battegay, "Hypoxia enhances vascular cell proliferation and angiogenesis in vitro via rapamycin (mTOR) -dependent signaling," The FASEB Journal, vol. 16, no. 8, pp. 771-780, 2002.

[32] R. E. Mills, K. R. Taylor, K. Podshivalova, D. B. McKay, and J. M. Jameson, "Defects in skin $\gamma \delta$ T cell function contribute to delayed wound repair in rapamycin-treated mice," The Journal of Immunology, vol. 181, no. 6, pp. 3974-3983, 2008.

[33] J. A. van der Vliet, M. C. M. Willems, B. M. de Man, R. M. L. M. Lomme, and T. Hendriks, "Everolimus interferes with healing of experimental intestinal anastomoses," Transplantation, vol. 82, no. 11, pp. 1477-1483, 2006.

[34] M. C. M. Willems, J. A. van der Vliet, B. M. de Man, J. A. W. M. van der Laak, R. M. L. M. Lomme, and T. Hendriks, "Persistent effects of everolimus on strength of experimental wounds in intestine and fascia," Wound Repair and Regeneration, vol. 18, no. 1, pp. 98-104, 2010.

[35] Y. Ekici, R. Emiroglu, H. Ozdemir, D. Aldemir, H. Karakayali, and M. Haberal, "Effect of rapamycin on wound healing: an experimental study," Transplantation Proceedings, vol. 39, no. 4, pp. 1201-1203, 2007.

[36] D. Kahn, C. W. Spearman, A. Mall et al., "The effect of rapamycin on the healing of the ureteric anastomosis and wound healing," Transplantation Proceedings, vol. 37, no. 2, pp. 830-831, 2005.

[37] A. Dutly, A. Gaspert, I. Inci, D. Schneiter, S. Korom, and W. Weder, "The influence of the rapamycin-derivate SDZ $\mathrm{RAD}$ on the healing of airway anastomoses," European Journal of Cardio-Thoracic Surgery, vol. 24, no. 1, pp. 154158, 2003.

[38] M. R. Ebadzadeh and M. Tavakkoli, "Lymphocele after kidney transplantation. Where are we standing now?" Urology Journal, vol. 5, pp. 144-148, 2008.

[39] M. L. d. Lima, C. A. C. Cotrim, J. C. Moro, R. Miyaoka, and C. A. L. D’Ancona, "Laparoscopic treatment of lymphoceles after renal transplantation," International Braz J Urol, vol. 38, no. 2, pp. 215-221, 2012.

[40] S. Huber, C. J. Bruns, G. Schmid et al., "Inhibition of the mammalian target of rapamycin impedes lymphangiogenesis," Kidney International, vol. 71, no. 8, pp. 771-777, 2007.

[41] A. C. Allison and E. M. Eugui, "Mycophenolate mofetil and its mechanisms of action," Immunopharmacology, vol. 47, no. 2-3, pp. 85-118, 2000.

[42] C. Morath, H. Reuter, V. Simon et al., "Effects of mycophenolic acid on human fibroblast proliferation, migration and AdhesionIn VitroandIn vivo," American Journal of Transplantation, vol. 8, no. 9, pp. 1786-1797, 2008.

[43] M. C. Willems, T. Hendriks, R. M. Lomme, B. M. de Man, and J. A. van der Vliet, "The effect of mycophenolate mofetil on early wound healing in a rodent model," Transplantation Direct, vol. 2, no. 6, p. e80, 2016. 
[44] G. M. Paul, R. Tambara Filho, and J. C. D. Repka, "Qualitative analysis of the deposit of collagen in bladder suture of rats treated with tacrolimus combined with mycophenolatemofetil," International Brazilian Journal of Urology, vol. 40, no. 2, pp. 257-265, 2014.

[45] C. Heinz, K. Heise, T. Hudde, and K. P. Steuhl, "Mycophenolate mofetil inhibits human Tenon fibroblast proliferation by guanosine depletion," British Journal of Ophthalmology, vol. 87, no. 11, pp. 1397-1398, 2003.

[46] P. C. Baer, S. Gauer, I. A. Hauser, J. E. Scherberich, and H. Geiger, "Effects of mycophenolic acid on human renal proximal and distal tubular cells in vitro," Nephrology Dialysis Transplantation, vol. 15, no. 2, pp. 184-190, 2000.

[47] I. Dubus, B. Vendrely, I. Christophe et al., "Mycophenolic acid antagonizes the activation of cultured human mesangial cells," Kidney International, vol. 62, no. 3, pp. 857-867, 2002.

[48] I. A. Hauser, L. Renders, H. H. Radeke, R. B. Sterzel, and M. Goppelt-Struebe, "Mycophenolate mofetil inhibits rat and human mesangial cell proliferation by guanosine depletion," Nephrology Dialysis Transplantation, vol. 14, pp. 58-63, 1999.

[49] C. Badid, M. Vincent, B. McGregor et al., "Mycophenolate mofetil reduces myofibroblast infiltration and collagen III deposition in rat remnant kidney," Kidney International, vol. 58, no. 1, pp. 51-61, 20001.

[50] B. Zanker, H. Schneeberger, U. Rothenpieler et al., "Mycophenolate mofetil-based, cyclosporine-free induction and maintenance immunosuppression," Transplantation, vol. 66, no. 1, pp. 44-49, 1998.

[51] K. Lopau, K. Syamken, P. Rubenwolf, H. Riedmiller, and C. Wanner, "Impact of mycophenolate mofetil on wound complications and lymphoceles after kidney transplantation," Kidney \& Blood Pressure Research, vol. 33, no. 1, pp. 52-59, 2010.

[52] J. F. Valente, D. Hricik, K. Weigel et al., "Comparison of sirolimus vs. mycophenolate mofetil on surgical complications and wound healing in adult kidney transplantation," American Journal of Transplantation, vol. 3, no. 9, pp. 1128-1134, 2003.

[53] J. Pascual, S. P. Berger, O. Witzke et al., "Everolimus with reduced calcineurin inhibitor exposure in renal transplantation," Journal of the American Society of Nephrology, vol. 29, no. 7, pp. 1979-1991, 2018.

[54] L. H. M. Pengel, L. Q. Liu, and P. J. Morris, "Do wound complications or lymphoceles occur more often in solid organ transplant recipients on mTOR inhibitors? A systematic review of randomized controlled trials," Transplant International, vol. 24, no. 12, pp. 1216-1230, 2011.

[55] G. M. Anstead, "Steroids, retinoids, and wound healing," Advances in Wound Care: The Journal for Prevention and Healing, vol. 11, pp. 277-285, 1998.

[56] C. Wicke, B. Halliday, D. Allen et al., "Effects of steroids and retinoids on wound healing," Archives of Surgery, vol. 135, no. 11, pp. 1265-70, 2000.

[57] L. R. Alberti, L. d. S. Vasconcellos, and A. Petroianu, "Influence of local or systemic corticosteroids on skin wound healing resistance," Acta Cirurgica Brasileira, vol. 27, no. 4, pp. 295-299, 2012.

[58] T. E. Pavlidis, I. N. Galatianos, B. T. Papaziogas et al., "Complete dehiscence of the abdominal wound and incriminating factors," The European journal of surgery = Acta chirurgica, vol. 167, pp. 351-355, 2001.

[59] G. Montagnino, S. Sandrini, B. Iorio et al., "A randomized exploratory trial of steroid avoidance in renal transplant patients treated with everolimus and low-dose cyclosporine," Nephrology Dialysis Transplantation: Official Publication of the European Dialysis and Transplant Association-European Renal Association, vol. 23, pp. 707-14, 2008.

[60] C. C. Rogers, M. Hanaway, R. R. Alloway, J. W. Alexander, R. E. Boardman, and E. S. Woodle, "Corticosteroid avoidance ameliorates lymphocele formation and wound healing complications associated with sirolimus therapy," Transplantation Proceedings, vol. 37, pp. 795-797, 2005.

[61] A. S. Wang, E. J. Armstrong, and A. W. Armstrong, "Corticosteroids and wound healing: clinical considerations in the perioperative period," The American Journal of Surgery, vol. 206, no. 3, pp. 410-417, 2013.

[62] C. Benavides, K. H. Mahmoud, R. Knight, C. Barcenas, B. D. Kahan, and C. T. Van Buren, "Rabbit antithymocyte globulin: a postoperative risk factor for sirolimus-treated renal transplant patients?" Transplantation Proceedings, vol. 37, no. 2, pp. 822-826, 2005.

[63] G. R. Pourmand, S. Dehghani, A. Saraji et al., "Relationship between post-kidney transplantation antithymocyte globulin therapy and wound healing complications," International journal of organ transplantation medicine, vol. 3, pp. 79-84, 2012.

[64] H. Andrade, D. Paluello, C. Batagello et al., "Obesity: a major risk factor for wound and parietal complications in renal transplantation," Transplantation, vol. 98, p. 522, 2014.

[65] K. L. Lentine, R. Delos Santos, D. Axelrod, M. A. Schnitzler, D. C. Brennan, and J. E. Tuttle-Newhall, "Obesity and kidney transplant candidates: how big is too big for transplantation," American Journal of Nephrology, vol. 36, no. 6, pp. 575-586, 2012.

[66] R. J. Lynch, D. N. Ranney, C. Shijie, D. S. Lee, N. Samala, and M. J. Englesbe, "Obesity, surgical site infection, and outcome following renal transplantation," Annals of Surgery, vol. 250, no. 6, pp. 1014-1020, 2009.

[67] S. A. Grim, C. M. Slover, H. Sankary, J. Oberholzer, E. Benedetti, and N. M. Clark, "Risk factors for wound healing complications in sirolimus-treated renal transplant recipients," Transplantation Proceedings, vol. 38, no. 10, pp. 3520-3523, 2006.

[68] R. J. Knight, M. Villa, R. Laskey et al., "Risk factors for impaired wound healing in sirolimus-treated renal transplant recipients," Clinical Transplantation, vol. 21, no. 4, pp. 460-465, 2007.

[69] H. Tedesco-Silva, J. Pascual, O. Viklicky et al., "Safety of everolimus with reduced calcineurin inhibitor exposure in de novo kidney transplants: an analysis from the randomized TRANSFORM study," Transplantation, vol. 103, no. 9, pp. 1953-1963, 2019.

[70] R. Vanholder, R. De Smet, R. De Smet et al., "Review on uremic toxins: classification, concentration, and interindividual variability," Kidney International, vol. 63, no. 5, pp. 1934-1943, 2003.

[71] J. Nayman, "Effect of renal failure on wound healing in dogs," Annals of Surgery, vol. 164, no. 2, pp. 227-235, 1966.

[72] J. F. Colin, P. Elliot, and H. Ellis, "The effect of uraemia upon wound healing: an experimental study," British Journal of Surgery, vol. 66, pp. 793-797, 1979.

[73] E. D. Kursh, L. Klein, J. Schmitt, S. Kayal, and L. Persky, “The effect of uremia on wound tensile strength and collagen formation," Journal of Surgical Research, vol. 23, no. 1, pp. 37-42, 1977. 
[74] K. Shindo and G. Kosaki, "Effects of chronic renal failure on wound healing in rats," Japanese Journal of Surgery, vol. 12, no. 1, pp. 46-51, 1982.

[75] N. Maroz and R. Simman, "Wound healing in patients with impaired kidney function," J Am Coll Clin Wound Spec, vol. 5, pp. 2-7, 2014.

[76] R. Sgonc and J. Gruber, "Age-related aspects of cutaneous wound healing: a mini-review," Gerontology, vol. 59, no. 2, pp. 159-164, 2013.

[77] G. S. Ashcroft, S. J. Mills, and J. J. Ashworth, "Ageing and wound healing," Biogerontology, vol. 3, no. 6, pp. 337-345, 2002.

[78] L. Duong, H. Radley, B. Lee et al., "Macrophage function in the elderly and impact on injury repair and cancer," Immunity \& Ageing, vol. 18, no. 1, p. 4, 2021.

[79] M. E. Swift, H. K. Kleinman, and L. A. DiPietro, "Impaired wound repair and delayed angiogenesis in aged mice," Laboratory investigation; a journal of technical methods and pathology, vol. 79, pp. 1479-1487, 1999.

[80] M. E. Swift, A. L. Burns, K. L. Gray, and L. A. DiPietro, “Agerelated alterations in the inflammatory response to dermal injury," Journ2al of Investigative Dermatology, vol. 117, no. 5, pp. 1027-1035, 2001.

[81] C. S. Rosenberg, "Wound healing in the patient with diabetes mellitus," Nursing Clinics of North America, vol. 25, pp. 247-261, 1990.

[82] P. Velander, C. Theopold, T. Hirsch et al., "Impaired wound healing in an acute diabetic pig model and the effects of local hyperglycemia," Wound Repair and Regeneration, vol. 16, no. 2, pp. 288-293, 2008.

[83] O. Z. Lerman, R. D. Galiano, M. Armour, J. P. Levine, and G. C. Gurtner, "Cellular dysfunction in the diabetic fibroblast," American Journal Of Pathology, vol. 162, no. 1, pp. 303-312, 2003.

[84] A. Terranova, "The effects of diabetes mellitus on wound healing," Plastic Surgical Nursing, vol. 11, no. 1, pp. 20-25, 1991.

[85] J. Xiang, S. Wang, Y. He, L. Xu, S. Zhang, and Z. Tang, "Reasonable glycemic control would help wound healing during the treatment of diabetic foot ulcers," Diabetes Therapy, vol. 10, no. 1, pp. 95-105, 2019.

[86] P. Greiffenstein and P. E. Molina, "Alcohol-induced alterations on host defense after traumatic injury," The Journal of Trauma, Injury, Infection, and Critical Care, vol. 64, no. 1, pp. 230-240, 2008.

[87] M. A. Choudhry and I. H. Chaudry, "Alcohol intoxication and post-burn complications," Frontiers in Bioscience, vol. 11, no. 1, pp. 998-1005, 2006.

[88] K. A. Radek, A. M. Matthies, A. L. Burns, S. A. Heinrich, E. J. Kovacs, and L. A. Dipietro, "Acute ethanol exposure impairs angiogenesis and the proliferative phase of wound healing," American Journal of Physiology. Heart and Circulatory Physiology, vol. 289, pp. H1084-H1090, 2005.

[89] K. A. Radek, E. J. Kovacs, R. L. Gallo, and L. A. DiPietro, "Acute ethanol exposure disrupts VEGF receptor cell signaling in endothelial cells," American Journal of Physiology. Heart and Circulatory Physiology, vol. 295, pp. H174-H184, 2008.

[90] M. J. Ranzer, L. Chen, and L. A. DiPietro, "Fibroblast function and wound breaking strength is impaired by acute ethanol intoxication," Alcoholism: Clinical and Experimental Research, vol. 35, no. 1, pp. 83-90, 2011.
[91] C. Ahn, P. Mulligan, and R. S. Salcido, "Smoking-the bane of wound healing," Advances in Skin \& Wound Care, vol. 12, no. 5, pp. 227-236, 2008.

[92] S. K. McMaster, M. J. Paul-Clark, M. Walters et al., "Cigarette smoke inhibits macrophage sensing of Gram-negative bacteria and lipopolysaccharide: relative roles of nicotine and oxidant stress," British Journal of Pharmacology, vol. 153, no. 3, pp. 536-543, 2008.

[93] L. T. Sørensen, S. Jørgensen, L. J. Petersen, U. Hemmingsen, J. Bülow, and S. Loft, "Acute effects of nicotine and smoking on blood flow, tissue oxygen, and aerobe metabolism of the skin and subcutis," Journal of Surgical Research, vol. 152, pp. 224-230, 2008.

[94] C. J Lauerman, "Surgical patient education related to smoking," AORN Journal, vol. 87, no. 3, pp. 599-609, 2008.

[95] M. A. M. Khalil, J. Tan, S. Khamis, M. A. Khalil, R. Azmat, and A. R. Ullah, "Cigarette smoking and its hazards in kidney transplantation," Advances in Medicine, vol. 2017, Article ID 6213814, 11 pages, 2017.

[96] J. Bergström, "Why are dialysis patients malnourished?" American Journal of Kidney Diseases, vol. 26, no. 1, pp. 229-241, 1995.

[97] M. Bossola, M. Muscaritoli, L. Tazza et al., "Malnutrition in hemodialysis patients: what therapy?" American Journal of Kidney Diseases, vol. 46, no. 3, pp. 371-386, 2005.

[98] S. H. Chung, J. J. Carrero, and B. Lindholm, "Causes of poor appetite in patients on peritoneal dialysis," Journal of Renal Nutrition, vol. 21, no. 1, pp. 12-15, 2011.

[99] D. Fouque, K. Kalantar-Zadeh, J. Kopple et al., “A proposed nomenclature and diagnostic criteria for protein-energy wasting in acute and chronic kidney disease," Kidney International, vol. 73, no. 4, pp. 391-398, 2008.

[100] R. Dukkipati and J. D. Kopple, "Causes and prevention of protein-energy wasting in chronic kidney failure," Seminars in Nephrology, vol. 29, no. 1, pp. 39-49, 2009.

[101] https://kidneyfoundation.cachefly.net/professionals/ KDOQI/guidelines_nutrition/nut_a15.html.

[102] P. P. Gogia, "Physiology of wound healing," in Clinical Wound Management, P. P. Gogia, Ed., Slack Incorporated, Thorofare, NJ, USA, 1995.

[103] A. C. Campos, A. K. Groth, and A. B. Branco, "Assessment and nutritional aspects of wound healing," Current Opinion in Clinical Nutrition and Metabolic Care, vol. 11, no. 3, pp. 281-288, 2008.

[104] Clinical Practice Guidelines for Nutrition in Chronic Renal Failure, "K/DOQI, National Kidney Foundation," American Journal of Kidney Diseases, vol. 35, pp. S1-S140, 2000.

[105] P. Ueno, C. Felipe, A. Ferreira et al., "Wound healing complications in kidney transplant recipients receiving everolimus," Transplantation, vol. 101, no. 4, pp. 844-850, 2017.

[106] S. N. Sehgal, H. Baker, and C. Vézina, "Rapamycin (AY22,989), a new antifungal antibiotic. II. Fermentation, isolation and characterization," Journal of Antibiotics, vol. 28, no. 10, pp. 727-732, 1975.

[107] M. G. Murgia, S. Jordan, and B. D. Kahan, "The side effect profile of sirolimus: a phase I study in quiescent cyclosporine-prednisone-treated renal transplant patients," Kidney International, vol. 49, no. 1, pp. 209-216, 1996.

[108] C. G. Groth, L. Bäckman, J.-M. Morales et al., "Sirolimus (Rapamycin)-based therapy in human renal transplantation," Transplantation, vol. 67, no. 7, pp. 1036-1042, 1999.

[109] H. Kreis, J.-M. Cisterne, W. Land et al., "Sirolimus in association with mycophenolate mofetil induction for the 
prevention of acute graft rejection in renal allograft Recipients12," Transplantation, vol. 69, no. 7, pp. 1252-1260, 2000.

[110] B. D. Kahan, "Efficacy of sirolimus compared with azathioprine for reduction of acute renal allograft rejection: a randomised multicentre study," The Lancet, vol. 356, no. 9225, pp. 194-202, 2000.

[111] S. M. Flechner, D. Goldfarb, C. Modlin et al., "Kidney transplantation without calcineurin inhibitor drugs: a prospective, randomized trial of sirolimus versus cyclosporine1," Transplantation, vol. 74, no. 8, pp. 1070-1076, 2002.

[112] R. M. Langer and B. D. Kahan, "Incidence, therapy, and consequences of lymphocele after sirolimus-cyclosporineprednisone immunosuppression in renal transplant recipients1," Transplantation, vol. 74, no. 6, pp. 804-808, 2002.

[113] P. G. Machado, C. R. Felipe, N. M. Hanzawa et al., "An openlabel randomized trial of the safety and efficacy of sirolimus vs. azathioprine in living related renal allograft recipients receiving cyclosporine and prednisone combination," Clinical Transplantation, vol. 18, no. 1, pp. 28-38, 2004.

[114] A. Lo, M. F. Egidi, L. W. Gaber et al., "Comparison of sirolimus-based calcineurin inhibitor-sparing and calcineurin inhibitor-free regimens in cadaveric renal transplantation," Transplantation, vol. 77, no. 8, pp. 1228-1235, 2004.

[115] G. Ciancio, G. W. Burke, J. J. Gaynor et al., “A randomized long-term trial of tacrolimus/sirolimus versus tacrolimus/ mycophenolate mofetil versus cyclosporine (NEORAL)/ sirolimus in renal transplantation. II. Survival, function, and protocol compliance at 1 year," Transplantation, vol. 77, no. 2, pp. 252-258, 2004.

[116] R. Kandaswamy, J. K. Melancon, T. Dunn et al., “A prospective randomized trial of steroid-free maintenance regimens in kidney transplant recipients-an interim analysis," American Journal of Transplantation, vol. 5, no. 6, pp. 1529-1536, 2005.

[117] A. F. Hamdy, A. E. El-Agroudy, M. A. Bakr et al., "Comparison of sirolimus with low-dose tacrolimus versus sirolimus-based calcineurin inhibitor-free regimen in live donor renal transplantation," American Journal of Transplantation, vol. 5, no. 10, pp. 2531-2538, 2005.

[118] T. S. Larson, P. G. Dean, M. D. Stegall et al., "Complete avoidance of calcineurin inhibitors in renal transplantation: a randomized trial comparing sirolimus and tacrolimus," American Journal of Transplantation, vol. 6, no. 3, pp. 514522, 2006.

[119] G. Martinez-Mier, M. T. Mendez-Lopez, L. F. Budar-Fernandez et al., "Living related kidney transplantation without calcineurin inhibitors: initial experience in a Mexican center," Transplantation, vol. 82, no. 11, pp. 1533-1536, 2006.

[120] M. D. Pescovitz, F. Vincenti, M. Hart et al., "Pharmacokinetics, safety, and efficacy of mycophenolate mofetil in combination with sirolimus or ciclosporin in renal transplant patients," British Journal of Clinical Pharmacology, vol. 64, pp. 758-771, 2007.

[121] A. O. Gaber, B. D. Kahan, C. Van Buren, S. L. Schulman, J. Scarola, and J. F. Neylan, "Comparison of sirolimus plus tacrolimus versus sirolimus plus cyclosporine in high-risk renal allograft recipients: results from an open-label, randomized trial," Transplantation, vol. 15, no. 9, pp. 1187-1195, 2008.

[122] E. L. Sampaio, P. G. Pinheiro-Machado, R. Garcia et al., "Mycophenolate mofetil vs. sirolimus in kidney transplant recipients receiving tacrolimus-based immunosuppressive regimen," Clinical Transplantation, vol. 22, pp. 141-149, 2008.

[123] D. Glotz, B. Charpentier, D. Abramovicz et al., "Thymoglobulin induction and sirolimus versus tacrolimus in kidney transplant recipients receiving mycophenolate mofetil and steroids," Transplantation, vol. 89, no. 12, pp. 1511-1517, 2010.

[124] H. Ekberg, C. Bernasconi, J. Noldeke et al., "Cyclosporine, tacrolimus and sirolimus retain their distinct toxicity profiles despite low doses in the Symphony study," Nephrology Dialysis Transplantation, vol. 25, no. 6, pp. 2004-2010, 2010.

[125] T. V. de Sandes Freitas, K. M. Harada, C. R. Felipe et al., "Steroid or tacrolimus withdrawal in renal transplant recipients using sirolimus," International Urology and $\mathrm{Ne}$ phrology, vol. 43, no. 4, pp. 1221-1228, 2011.

[126] S. M. Flechner, A. Gurkan, A. Hartmann et al., "A randomized, open-label study of sirolimus versus cyclosporine in primary de novo renal allograft recipients," Transplantation, vol. 95, no. 10, pp. 1233-1241, 2013.

[127] K. H. Huh, J. G. Lee, J. Ha et al., "De novo low-dose sirolimus versus mycophenolate mofetil in combination with extended-release tacrolimus in kidney transplant recipients: a multicentre, open-label, randomized, controlled, non-inferiority trial," Nephrology Dialysis Transplantation, vol. 32, no. 8, pp. 1415-1424, 2017.

[128] S. Vítko, R. Margreiter, W. Weimar et al., "B201 Study Group. Three-year efficacy and safety results from a study of everolimus versus mycophenolate mofetil in de novo renal transplant patients," American Journal of Transplantation, vol. 5, pp. 2521-2530, 2005.

[129] M. I. Lorber, S. Mulgaonkar, K. M. H. Butt et al., "Everolimus versus mycophenolate mofetil in the prevention of rejection in de novo renal transplant recipients: a 3-year randomized, multicenter, phase III study," Transplantation, vol. 80, no. 2, pp. 244-252, 2005.

[130] L. Chan, S. Greenstein, M. A. Hardy et al., "Multicenter, randomized study of the use of everolimus with tacrolimus after renal transplantation demonstrates its effectiveness," Transplantation, vol. 85, no. 6, pp. 821-826, 2008

[131] R. Margreiter, Š. Vitko, J. Whelchel et al., "Post-operative tissue regeneration in renal transplantation: comparable outcome with everolimus or mmf," Transplantation, vol. 86, no. 2 S, p. $188,2008$.

[132] L. Albano, F. Berthoux, M.-C. Moal et al., "Incidence of delayed graft function and wound healing complications after deceased-donor kidney transplantation is not affected by de novo everolimus," Transplantation, vol. 88, no. 1, pp. 69-76, 2009.

[133] H. T. Silva Jr, D. Cibrik, T. Johnston et al., "Everolimus plus reduced-exposure CsA versus mycophenolic acid plus standard-exposure CsA in renal-transplant recipients," American Journal of Transplantation, vol. 10, no. 6, pp. 1401-1413, 2010.

[134] M. Cooper, A. C. Wiseman, G. Zibari et al., "Wound events in kidney transplant patients receiving de novo everolimus: a pooled analysis of three randomized controlled trials," Clinical Transplantation, vol. 27, no. 6, pp. E625-E635, 2013.

[135] D. Cibrik, H. T. Silva Jr, A. Vathsala et al., "Randomized trial of everolimus-facilitated calcineurin inhibitor minimization over 24 months in renal transplantation," Transplantation, vol. 95, no. 7, pp. 933-942, 2013.

[136] S. J. Chadban, J. M. Eris, J. Kanellis et al., “A randomized, controlled trial of everolimus-based dual immunosuppression versus standard of care in de novo kidney transplant 
recipients," Transplant International, vol. 27, no. 3, pp. 302-311, 2014.

[137] B. Nashan, G. Mvander, H. Holdaas et al., "Impact on wound healing events after early conversion to everolimus in de novo renal transplant recipients: 24-month results from the randomized ELEVATE study. [abstract]," American Journal of Transplantation, vol. 16, no. 3, 2016.

[138] Y. Qazi, D. Shaffer, B. Kaplan et al., "Efficacy and safety of everolimus plus low-dose tacrolimus versus mycophenolate mofetil plus standard-dose tacrolimus inDe NovoRenal transplant recipients: 12-month data," American Journal of Transplantation, vol. 17, no. 5, pp. 1358-1369, 2017.

[139] C. Sommerer, B. Suwelack, D. Dragun et al., "An open-label, randomized trial indicates that everolimus with tacrolimus or cyclosporine is comparable to standard immunosuppression in de novo kidney transplant patients," Kidney International, vol. 96, no. 1, pp. 231-244, 2019.

[140] H. Y. Tiong, S. M. Flechner, L. Zhou et al., "A systematic approach to minimizing wound problems for de novo sirolimus-treated kidney transplant recipients," Transplantation, vol. 87, no. 2, pp. 296-302, 2009.

[141] https://clinicaltrials.gov/ct2/show/NCT03468478 accessed on 19th May 2021.

[142] S. Weiss, A. Weissenbacher, R. Sucher et al., "Outcome analysis of laparoscopic incisional hernia repair and risk factors for hernia recurrence in liver transplant patients," Clinical Transplantation, vol. 29, no. 10, pp. 866-871, 2015.

[143] H. Scheuerlein, F. Rauchfuss, A. Gharbi, M. Heise, and U. Settmacher, "Laparoscopic incisional hernia repair after solid-organ transplantation," Transplantation Proceedings, vol. 43, no. 5, pp. 1783-1789, 2011.

[144] P. T. Kennealey, C. S. Johnson, A. J. Tector, and D. J. Selzer, "Laparoscopic incisional hernia repair after solid-organ transplantation," Archives of Surgery, vol. 144, no. 3, pp. 228-233, 2009.

[145] J. Pascual, C. Galeano, D. Celemín et al., "Uneventful thoracic healing with everolimus after aortic valve replacement," The Annals of Thoracic Surgery, vol. 84, no. 1, pp. 271-272, 2007.

[146] A. Heble, M. D. Everitt, J. Gralla, S. D. Miyamoto, M. Lahart, and J. Eshelman, "Safety of mTOR inhibitor continuation in pediatric heart transplant recipients undergoing surgical procedures," Pediatric Transplantation, vol. 22, no. 1, p. e13093, 2018.

[147] L. Schwarz, F. Cauchy, F. Conti et al., "Preliminary report of major surgery in liver transplant recipients receiving $\mathrm{m}$-TOR inhibitors without therapeutic discontinuation," World Journal of Surgery, vol. 38, no. 12, pp. 3193-3198, 2014.

[148] J. M. Campistol, P. Cockwell, F. Diekmann et al., "Practical recommendations for the early use of $\mathrm{m}$-TOR inhibitors (sirolimus) in renal transplantation," Transplant International, vol. 22, no. 7, pp. 681-687, 20091.

[149] M. P. W. Smith, C. G. Newstead, N. Ahmad et al., "Poor tolerance of sirolimus in a steroid avoidance regimen for renal transplantation," Transplantation, vol. 85, no. 4, pp. 636-639, 2008.

[150] B. Nashan and F. Citterio, "Wound healing complications and the use of mammalian target of rapamycin inhibitors in kidney transplantation," Transplantation, vol. 94, no. 6, pp. 547-561, 2012.

[151] B. Kaplan, Y. Qazi, and J. R. Wellen, "Strategies for the management of adverse events associated with mTOR inhibitors," Transplantation Reviews, vol. 28, no. 3, pp. 126-133, 20141.
[152] D. J. Fitzgerald, K. A. Radek, M. Chaar, D. E. Faunce, L. A. DiPietro, and E. J. Kovacs, "Effects of acute ethanol exposure on the early inflammatory response after excisional injury," Alcoholism: Clinical and Experimental Research, vol. 31, no. 2, pp. 317-323, 2007. 